\title{
Pituitary Adenylate Cyclase-Activating Polypeptide Expression and Modulation of Neuronal Excitability in Guinea Pig Cardiac Ganglia
}

\author{
Karen M. Braas, Victor May, Susan A. Harakall, Jean C. Hardwick, and Rodney L. Parsons \\ Department of Anatomy and Neurobiology, The University of Vermont, College of Medicine, Burlington, Vermont 05405
}

Cardiac output is regulated by the coordinate interactions of stimulatory sympathetic and inhibitory parasympathetic signals. Intracardiac parasympathetic ganglia are integrative centers of cardiac regulation, and modulation of the parasympathetic drive on the heart is accomplished by altering intrinsic cardiac ganglion neuron excitability. The pituitary adenylate cyclase-activating polypeptide (PACAP)/vasoactive intestinal peptide (VIP) family of peptides modulates cardiac function, and in guinea pig heart, PACAP appears to act directly on intrinsic parasympathetic cardiac ganglia neurons through PACAP-selective receptors. A multidisciplinary project tested whether cardiac PACAP peptides act through PACAP-selective receptors as excitatory neuromodulators amplifying the parasympathetic inhibition from guinea pig cardiac ganglia. The in vivo sources of regulatory PACAP peptides were localized immunocytochemically to neuronal fibers and a subpopulation of intrinsic postganglionic cardiac neurons. RT-PCR confirmed that cardiac ganglia expressed proPACAP transcripts and have PACAP peptide biosynthetic capabilities. Messenger RNA encoding PACAP-selective PAC1 receptor isoforms were also present in cardiac ganglia. Alternative splicing of PAC1 receptor transcripts produced predominant expression of the very short variant with neither HIP nor HOP cassettes; lower levels of the PAC1HOP2 receptor mRNA were present. Almost all of the parasympathetic neurons expressed membrane-associated PAC1 receptor proteins, localized immunocytochemically, which correlated with the population of cells that responded physiologically to PACAP peptides. PACAP depolarized cardiac ganglia neurons and increased neuronal membrane excitability. The rank order of peptide potency on membrane excitability in response to depolarizing currents was PACAP27 $>$ PACAP38 $>$ VIP. The PACAP-induced increase in excitability was not a function of membrane depolarization nor was it caused by alterations in action potential configuration. These results support roles for PACAP peptides as integrative modulators amplifying, through PACAP-selective receptors, the parasympathetic cardiac ganglia inhibition of cardiac output.

Key words: pituitary adenylate cyclase activating polypeptide; vasoactive intestinal peptide; PACAP receptor; cardiac ganglia; parasympathetic ganglia; neuropeptide receptors; autonomic nervous system
Cardiac output reflects the net dynamic opposing excitatory sympathetic noradrenergic and inhibitory parasympathetic cholinergic signals (Loffelholz and Pappano, 1985). Although classic models regarded autonomic ganglia as simple relay stations propagating regulatory signals from sympathetic and parasympathetic efferent pathways, more recent studies have demonstrated that the neurochemical modulation of intracardiac parasympathetic ganglia is more complex. Parasympathetic cardiac ganglia receive not only cholinergic preganglionic inputs, but also peptidergic afferent and sympathetic postganglionic signals that affect the activity of intrinsic cardiac parasympathetic neurons (Loffelholz and Pappano, 1985; Konopka et al., 1992; Randall and Wurster, 1994; Hardwick et al., 1995; Kennedy et al., 1998). Furthermore, because most of the cholinergic cardiac neurons coexpress other endogenous neuromodulators, including nitric oxide, somatostatin, neuropeptide Y (NPY), vasoactive intestinal peptide (VIP),

Received May 4, 1998; revised Sept. 4, 1998; accepted Sept. 9, 1998.

This work was supported by American Heart Association Grant-in-Aids 975043N (R.L.P.) and 94015540 (K.M.B.), and Grants NS-23978 (R.L.P.), HD-27468 (V.M. and K.M.B.), and NS-01636 (V.M.) from National Institutes of Health. We thank Eric Gauthier for assistance with the confocal microscopy, Peter Durda for oligonucleotide and probe synthesis, Dr. Cynthia Forehand for assistance with fluorescent microscopy, Michelle Calupca for dissociated neurons, and Brie Guilmette for initial cloning and sequencing of the guinea pig proPACAP cDNA.

Correspondence should be addressed to Dr. Rodney L. Parsons, Department of Anatomy and Neurobiology, The University of Vermont, College of Medicine, Given Health Science Complex, Burlington, VT 05405.

Copyright (C) 1998 Society for Neuroscience $\quad 0270-6474 / 98 / 189766-14 \$ 05.00 / 0$ and enkephalins, the resultant parasympathetic drive on the heart represents an integration of parasympathetic preganglionic inputs, as well as extrinsic and intrinsic signals that modulate cardiac ganglia neuron excitability (Steele et al., 1994; Mawe et al., 1996; Kennedy et al., 1998).

Among cardiovasoregulatory neuropeptides, pituitary adenylate cyclase-activating polypeptide (PACAP), a member of the $\mathrm{VIP} /$ secretin/glucagon family of peptides, has potent cardiovascular functions (Warren et al., 1991; Ishizuka et al., 1992; Basler et al., 1995; Champion et al., 1996; Cardell et al., 1997). The 175 amino acid proPACAP precursor molecule is tissue-specifically processed to either the $\alpha$-amidated PACAP38 [proPACAP $(131-$ 168)] or PACAP27 [proPACAP(131-157)] (Miyata et al., 1989; Kimura et al., 1990; Ogi et al., 1990); both peptides exert tissuespecific effects through activation of specific isoforms of the G-protein-coupled PACAP-selective (PAC1) receptors [The names of the receptor subtypes in this manuscript conform to the nomenclature approved by the International Union of Pharmacology (IUPHAR). The PAC1 receptor has been termed alternatively as the type I-PACAP, PACAP ${ }_{1}$, or PVR1 receptor. The VPAC1 receptor replaces the $\mathrm{VIP}_{1} / \mathrm{PACAP}, \mathrm{VIP} 1 \mathrm{R}$, and PVR2 receptor nomenclature; the $\mathrm{VPAC} 2$ receptor supplants $\mathrm{VIP}_{2} /$ PACAP, VIP2R, and PVR3.], and/or through the VPAC1- or VPAC2-nonselective receptors (Ishihara et al., 1992; Hashimoto et al., 1993; Hosoya et al., 1993; Lutz et al., 1993; Spengler et al., 1993; Inagaki et al., 1994). Although many species-specific 
PACAP effects have been attributed to direct actions on vascular smooth muscle and/or cardiac myocytes, some studies have suggested that PACAP has potent direct neuroregulatory effects on cardiac ganglia function with consequences on cardiac output (Seebeck et al., 1996; Yonezawa et al., 1996; Hirose et al., 1997). In guinea pig heart tissue, for example, PACAP elicits negative chronotropic effects through stimulation of acetylcholine release from intracardiac neurons (Seebeck et al., 1996). These effects on intrinsic cardiac neurons appear to be mediated by PACAPselective receptors, implicating PACAP participation in the parasympathetic control of cardiac function.

The present studies were designed to test the hypothesis that cardiac PACAP peptides act as excitatory neuromodulators amplifying the parasympathetic inhibition from guinea pig cardiac ganglia. Studies of the direct electrophysiological responses of cardiac ganglia neurons to PACAP were complemented with molecular and morphological approaches to elucidate the expression of PACAP and PACAP-selective receptors in ganglia tissues. We demonstrate that PACAP peptides are expressed in neuronal fibers and a subpopulation of intrinsic cardiac ganglia parasympathetic neurons, which correlates with endogenous proPACAP mRNA expression. PACAP peptides exert potent excitatory influences through cardiac neuron PAC1 receptors, amplifying the parasympathetic inhibitory drive on the heart. These results implicate PACAP peptides among the principal integrative peptidergic systems in the guinea pig parasympathetic cardiac ganglia that determine cardiac output.

\section{MATERIALS AND METHODS}

Tissue preparation. The studies used parasympathetic postganglionic neurons in cardiac ganglia whole-mount preparations from adult Hartley guinea pigs $(250-300 \mathrm{gm}$, mixed sex). Animals were euthanized by stunning or decapitation followed by exsanguination, and the hearts were removed and dissected in cold Krebs' solution. The cardiac ganglia lying in the epicardium of the atrial wall was exposed by removal of muscle bundles and connective tissue layers as described previously (Hardwick et al., 1995, 1997; Mawe et al., 1996; Kennedy et al., 1998). For some studies, ganglia were dissociated, and the neurons were plated onto glass coverslips (Jeong and Wurster, 1997).

Immunocytochemistry. Morphological localization was performed as described previously (Braas et al., 1994a; May et al., 1995; Mawe et al., 1996; Brandenburg et al., 1997). In brief, PACAP immunoreactivity was localized in atrial whole-mount preparations fixed with $2 \%$ paraformaldehyde and $0.2 \%$ picric acid in $0.1 \mathrm{M}$ sodium phosphate buffer, $\mathrm{pH} 7.4$, containing $150 \mathrm{~mm} \mathrm{NaCl}$ (PBS) at $4^{\circ} \mathrm{C}$ for $2 \mathrm{hr}$. After washing, the tissues were permeabilized and blocked in PBS containing 5\% normal goat serum and $0.5 \%$ Triton X-100 for $30 \mathrm{~min}$, and incubated with 1:5001:2000 rabbit anti-PACAP (PACAP27 antiserum, RAS-8922N; PACAP38 antiserum, RAS-8920N; Peninsula Laboratories, Belmont, CA) and 1:2000 mouse anti-microtubule-associated protein-2 (MAP-2; Boehringer Mannheim, Indianapolis, IN) for $24 \mathrm{hr}$ at $4^{\circ} \mathrm{C}$. The whole mounts were washed and incubated for $90 \mathrm{~min}$ at $22^{\circ} \mathrm{C}$ with indocarbocyanine (Cy3)-labeled anti-rabbit IgG and fluorescein isothiocyanate (FITC)-labeled goat anti-mouse IgG (Jackson ImmunoResearch Laboratories, West Grove, PA).

To localize the PAC1 receptor, neurons were labeled with affinitypurified antisera raised against the extracellular amino terminal region of the receptor (ERIQRANDLMGLNESSPGC; amino acid residues 3553) (May et al., 1998). Atrial whole-mount preparations were fixed and stained as described above. Dissociated cardiac ganglion neurons were fixed for 15 min with $4 \%$ paraformaldehyde in $0.1 \mathrm{M}$ sodium phosphate buffer, $\mathrm{pH} 7.4$, and washed with the same buffer. The neurons were permeabilized with $0.1 \%$ Triton $\mathrm{X}-100$, blocked with $2 \%$ normal donkey serum, and incubated for $24 \mathrm{hr}$ at $4^{\circ} \mathrm{C}$ with 1:2000 anti-PAC1 receptor and 1:2000 anti-MAP-2. The cells were exposed to species-specific antibodies as described.

The specificities of the stains were determined by absorption and method controls including use of preimmune serum, omission of either primary or secondary antisera, and preabsorption of primary antisera with immunogen, or homologous/related peptides, as described previously (Braas et al., 1994a; May et al., 1995, 1998; Mawe et al., 1996; Brandenburg et al., 1997). No staining was observed in tissues under these control staining conditions. The PACAP antisera have been characterized by radioimmunoassay to be highly specific and lack crossreactivity with other peptides (Brandenburg et al., 1997) (Peninsula Laboratories). The PAC1 receptor antiserum was characterized by Western analysis (May et al., 1998) and also failed to stain cell lines known to express only VPAC receptors (V. May, unpublished results).

Messenger RNA analysis. Total RNA was prepared from individual guinea pig atrial whole-mount preparations containing the cardiac ganglia using the RNA STAT-60 total RNA isolation reagent (Tel-Test B, Friendswood, TX) as described previously (Braas et al., 1994a, b; May and Braas, 1995; Brandenburg et al., 1997; Kennedy et al., 1998). Firststrand cDNA was produced using SuperScript II Reverse Transcriptase and oligo dT primers with the SuperScript Preamplification System (Gibco-BRL Life Technologies, Grand Island, NY). Single-stranded cDNA was amplified 30-40 cycles as described previously with Expand High Fidelity PCR System thermostable DNA polymerase mixture (Boehringer Mannheim) using the AmpliWax PCR gem-facilitated hot start (Perkin Elmer, Norwalk, CT) (May and Braas, 1995; Braas and May, 1996; Brandenburg et al., 1997). PCR was conducted using primer templates specific to regions of the rat proPACAP or proPAC1 receptor transcripts with high interspecies homology (Table 1). Amplified products were resolved on $1.6 \%$ agarose gels and visualized by ethidium bromide staining under UV illumination. Routine controls included cDNA synthesis in the absence of either RNA or reverse transcriptase; amplification with omission of template, primers, or DNA polymerase failed to yield products (data not shown). Synthesis of cDNA and amplification of samples from tissues with established presence or absence of PACAP or PAC1 receptor expression were compared; each transcript was examined with multiple primer pairs designed to span multiple exons and different regions of the molecule.

Verification of the reverse transcription proPACAP PCR products was performed using sequence-specific hybridization (Brandenburg et al., 1997). The amplified DNA, fractionated on agarose gels, was denatured, neutralized, and rapidly downward-transferred to Nytran-Plus membranes (Schleicher and Schuell, Keene, NH). The membranes were hybridized at $65^{\circ} \mathrm{C}$ for $48 \mathrm{hr}$ with the radiolabeled synthetic antisense internal oligonucleotide probe, 5'-TGGTCTGATCCCAGGGAAGCTGAGTCCGGCGGCAGGTGAACA-3', washed under high stringency, and apposed to REFLECTION film (DuPont NEN, Wilmington, DE) as described previously (Brandenburg et al., 1997).

The identities of the peptide and receptor amplified products were confirmed by restriction enzyme digestion. The product bands were excised from the agarose gels, frozen/thawed, eluted by microfiltration through $0.45 \mu \mathrm{m}$ polyvinylidene fluoride membranes (Millipore, Bedford, MA), and precipitated in the presence of $20 \mu \mathrm{g}$ of glycogen. The 445 base pair proPACAP product amplified with primers PCPX1 and PCPX2 was digested with Hph I, Ban II, Mse I, or BstX I for diagnostic restriction analysis. Similarly, the major 303 base pair PAC1 receptor product obtained using primers PACAPR1 and PACAPR2, corresponding to the isoform without cassettes in the third cytoplasmic loop coding region, was digested with SfaN I, Hae III or Hin F I. The 447-nucleotide receptor product amplified using PACAPRX3 and PACAPRX4, which span the alternative splice site in the region coding the PAC1 receptor amino terminal extracellular domain, was digested with PflF I, Tsp509 I, Bbs I, or Tse I.

For sequencing of the PACAP and PAC1 receptor PCR products, the ends of the purified amplified fragments were polished with $P f u$ DNA polymerase, and the blunt-ended products were ligated into the pCRScript Amp SK $(+)$ cloning vector (Stratagene, La Jolla, CA) using the Srf I restriction endonuclease and T4 DNA ligase. These ligated vectors were used for transformation into MAX Efficiency DH5 $\alpha$ F'IQ competent cells (Gibco-BRL Life Technologies, Inc.), and the presence of inserts in positive colonies was verified by PCR. Automated fluorescent dideoxy dye terminator sequencing was performed in both directions using the T3 and T7 primer sites. Sequence analyses were performed using the DNASTAR software (Lasergene, Madison, WI).

Electrophysiology. For electrophysiological recording, the atrial wholemount preparations were maintained in a standard Krebs' solution containing (in mM): $121 \mathrm{NaCl}, 5.9 \mathrm{KCl}, 2.5 \mathrm{CaCl}_{2}, 1.2 \mathrm{MgCl}_{2}, 25 \mathrm{NaHCO}_{3}$, $1.2 \mathrm{NaH}_{2} \mathrm{PO}_{4}$, and 8 glucose, maintained at pH 7.4 by aeration with $95 \%$ $\mathrm{O}_{2} / 5 \% \mathrm{CO}_{2}$. The intracardiac ganglia within the tissue epicardia were exposed by removal of the atrial muscle and blood vessels, facilitating 
Table 1. RT-PCR gene-specific primers

\begin{tabular}{|c|c|c|c|c|c|}
\hline $\begin{array}{l}\text { Oligonucleo- } \\
\text { tide Primers }\end{array}$ & Specificity $^{a}$ & Sequence & Position $^{b}$ & $\begin{array}{l}\text { Predicted } \\
\text { product } \\
\text { size }^{c}(\mathrm{bp})\end{array}$ & $\begin{array}{l}\text { Annealing } \\
\text { temperature }\end{array}$ \\
\hline $\begin{array}{l}\text { PCP1 } \\
\text { PCP2 }\end{array}$ & $\begin{array}{l}\text { ProPACAP mRNA } \\
\text { (rat neuronal proPACAP } \\
\text { mRNA) }\end{array}$ & $\begin{array}{l}\text { 5'-ATGCCTCTCTGGTTGTGATTC-3' } \\
\text { 5'-CGCTATTCGGCGTCCTTTGTT-3' }\end{array}$ & $\begin{array}{c}486-506 \\
1071-1091\end{array}$ & $606 / 612$ & $57^{\circ}$ \\
\hline $\begin{array}{l}\text { PCPX1 } \\
\text { PCPX2 }\end{array}$ & $\begin{array}{l}\text { ProPACAP mRNA } \\
\text { (5' coding region; cross species) }\end{array}$ & $\begin{array}{l}\text { 5'-ATGACCATGTGTAGCGGAGCAAGGT-3' } \\
\text { 5'-GGTAGCGGCTGTAGCTGTCTGTGAA-3' }\end{array}$ & $\begin{array}{l}573-597 \\
978-1002\end{array}$ & $430 / 433$ & $61^{\circ}$ \\
\hline $\begin{array}{l}\text { PCPX5 } \\
\text { PCPX6 }\end{array}$ & $\begin{array}{l}\text { ProPACAP mRNA } \\
\text { (3' coding region; cross species) }\end{array}$ & $\begin{array}{l}\text { 5'-AGGACGGAAACCCGCTGCAAGACTT-3' } \\
\text { 5'-GCTACAAGTACGCTATTCGGCGTCCTTTGT-3' }\end{array}$ & $\begin{array}{c}703-727 \\
1072-1101\end{array}$ & 399 & $62^{\circ}$ \\
\hline $\begin{array}{l}\text { PACAPR1 } \\
\text { PACAPR2 }\end{array}$ & $\begin{array}{l}\text { PAC1 receptor mRNA (third } \\
\text { cytoplasmic loop splice vari- } \\
\text { ants; cross species) }\end{array}$ & $\begin{array}{l}\text { 5'-CTTGTACAGAAGCTGCAGTCCCCAGACATG-3' } \\
\text { 5'-CCGGTGCTTGAAGTCCATAGTGAAGTAACGG- } \\
\text { TTCACCTT-3' }\end{array}$ & $\begin{array}{l}1078-1107 \\
1510-1548\end{array}$ & $303-471^{d}$ & $60^{\circ}$ \\
\hline $\begin{array}{l}\text { PACAPRX3 } \\
\text { PACAPRX4 }\end{array}$ & $\begin{array}{l}\text { PAC1 receptor mRNA (amino } \\
\text { terminal extracellular domain } \\
\text { splice variants; cross species) }\end{array}$ & $\begin{array}{l}\text { 5'-TGCCCTGAGGTCTTCCGGATCTTCAAC-3' } \\
\text { 5'-AATGAACAGCCAGAAGTAGTTGGACAC-3' }\end{array}$ & $\begin{array}{l}316-342 \\
799-825\end{array}$ & $447 / 510^{d}$ & $58^{\circ}$ \\
\hline
\end{tabular}

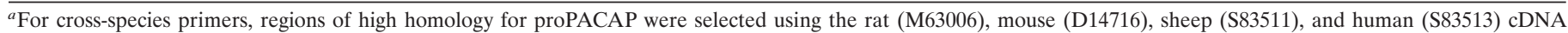
sequences. Sequences used for identifying PAC1 receptor homologous regions included the rat (Z23272), mouse (D82935), human (D17516), and cow (D17290).

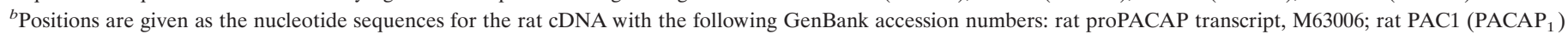
short HIP/HOP receptor transcript, Z23272.

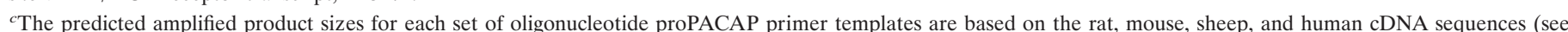

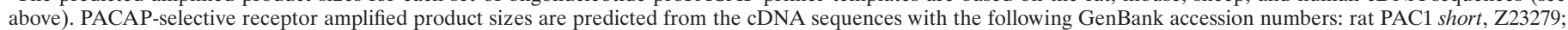

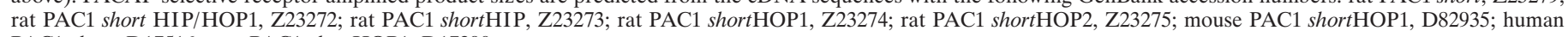
PAC1 short, D17516; cow PAC1 shortHOP1, D17290.

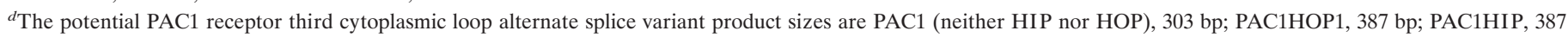

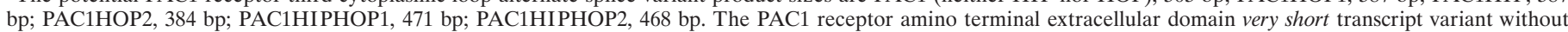

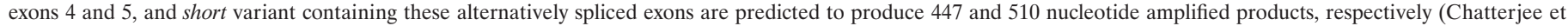
al., 1997).

visualization and impalement of the parasympathetic neurons. The whole-mount preparations were pinned in a $2.5 \mathrm{ml}$ Sylgard-lined chamber and superfused continuously at a rate of $6-10 \mathrm{ml} / \mathrm{min}$ with oxygenated Krebs' solution at $35-37^{\circ} \mathrm{C}$. For specific experiments, the direct effects of PACAP were examined in the presence of $300 \mathrm{~nm}$ tetrodotoxin in a calcium-deficient buffer (no added calcium with $5 \mathrm{~mm}$ magnesium); alternatively, $200 \mu \mathrm{M}$ cadmium was added to the Krebs' solution. Electrophysiological recordings were obtained using an Axoclamp-2A amplifier from guinea pig cardiac ganglia neurons impaled with $2 \mathrm{M} \mathrm{KCl-filled}$ glass microelectrodes (40-60 $\mathrm{M} \Omega$ ) as described previously (Hardwick et al., 1995, 1997; Kennedy et al., 1998). PACAP27, PACAP38, or VIP were applied by either superfusion or local pressure ejection (Picospritzer; General Valve, Fairfield, NJ) through 5- to 10- $\mu \mathrm{m}$-diameter pipettes positioned 50-100 $\mu \mathrm{m}$ from the neurons. Stock solutions of the peptides were prepared in $1 \mathrm{~mm} \mathrm{HCl}$ and were diluted to final concentrations with Krebs' solution; peptides applied by pressure ejection were used at $50 \mu \mathrm{M}$ concentrations.

\section{RESULTS}

\section{PACAP immunoreactivity is expressed in cardiac ganglion neuronal fibers and soma}

PACAP peptides have been shown to modulate cardiac function, and in guinea pig atrial tissue, PACAP appeared to exert negative chronotropic effects through a PACAP-selective pattern of stimulated acetylcholine release from parasympathetic intracardiac neurons (Seebeck et al., 1996). Because the in vivo sources of this regulatory PACAP were unclear, the presence of PACAP peptides in the neural elements within the guinea pig cardiac ganglia was examined using morphological and molecular techniques. The postganglionic cardiac neurons of the atrial whole-mount preparations are essentially cell monolayers, allowing localization of PACAP in fibers and neurons in situ (Hardwick et al., 1995;
Mawe et al., 1996; Kennedy et al., 1998). We and others have established that specific neuropeptides and transmitters are preferentially colocalized in cardiac ganglia fibers and neurons (Steele et al., 1994; Hardwick et al., 1995; Kennedy et al., 1998). All of the parasympathetic neurons are cholinergic and exhibit MAP-2 immunoreactivity, and subpopulations of intrinsic neurons express other modulators, including neuropeptides. Concomitant immunocytochemical staining for PACAP peptides and MAP-2 defined the structural relationships between the PACAPimmunoreactive elements and neural tissue within the parasympathetic ganglia (Fig. $1 A, B$ ). PACAP-immunoreactive neuronal fibers were identified within cardiac ganglia and interganglionic fiber tracts (Fig. 1B). The majority of the PACAP-containing fibers and varicosities in individual ganglia surrounded neuronal clusters, often forming pericellular complexes surrounding MAP2-positive neurons. In addition, peptide immunoreactivity was observed in processes within large and small nerve trunks coursing across the whole-mount preparations; the PACAPimmunoreactive fibers did not exit these fiber bundles to innervate adjacent myocardial or vascular tissues (data not shown). The neuronal fiber staining patterns were similar with antisera against either PACAP27 or PACAP38, although the PACAP27 antisera produced more consistent staining; no staining was observed in absorption and method control preparations (data not shown).

A subpopulation of the MAP-2-immunoreactive parasympathetic intracardiac neurons exhibited PACAP immunoreactivity (Fig. 1A). The staining intensity and number of PACAP-labeled 

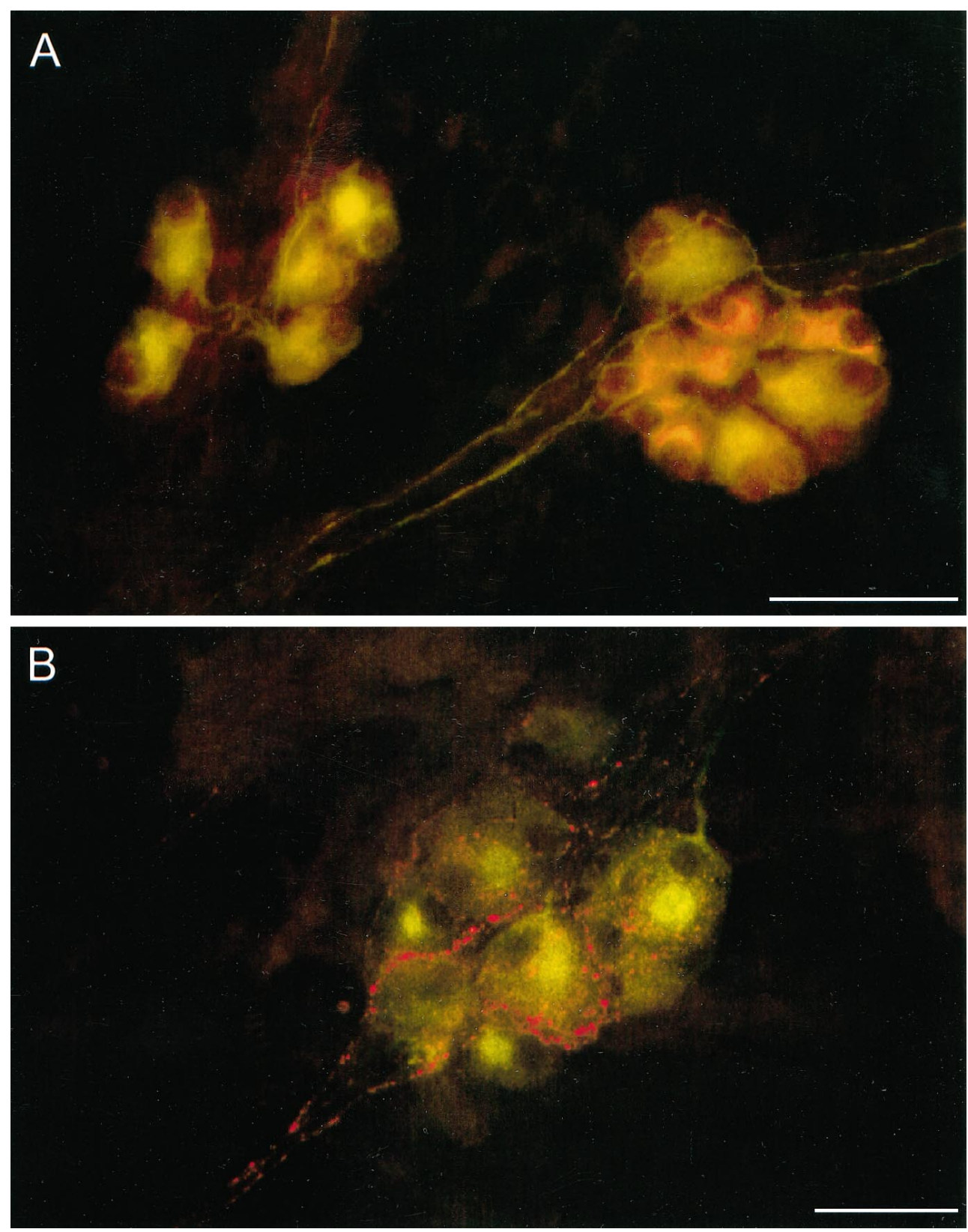

Figure 1. Neural elements within the cardiac parasympathetic ganglia exhibit PACAP peptide immunoreactivity. Guinea pig atrial whole-mount preparations were fixed, immunocytochemically labeled for PACAP27 (Cy3, red) and MAP-2 (FITC, green), and examined under fluorescence microscopy. A, PACAP immunoreactivity was localized to a subpopulation of MAP-2-labeled ganglia neurons. $B$, PACAP peptide staining was prominent in fiber trunks and processes frequently enveloping the principal parasympathetic neurons. Scale bar, $50 \mu \mathrm{m}$.

perikarya were heterogeneous among ganglia; a small population of the total parasympathetic neurons appeared to demonstrate preferential cytoplasmic labeling with the PACAP38 antisera. This pattern of PACAP expression in cardiac ganglia neurons was similar to expression in a number of other autonomic ganglia (Mulder et al., 1995; Tobin et al., 1995; Zhang et al., 1995; Sundler et al., 1996; Brandenburg et al., 1997; Elsas et al., 1997). Together, these results indicated that PACAP expression in the cardiac ganglia may have both extrinsic and intrinsic components with integrative roles in modulating cardiac function.

\section{Cardiac ganglia express proPACAP mRNA}

The identification of cardiac ganglion neuron PACAP immunoreactivities was consistent with intrinsic PACAP production. A requisite for endogenous peptide production is the expression of mRNA encoding the proPACAP precursor molecule. To investigate whether intrinsic cardiac neurons have the biosynthetic capability to synthesize PACAP peptides, the expression of
proPACAP mRNA was examined using RT-PCR. First-strand cDNA synthesized from total RNA extracted from cardiac ganglia whole-mount preparations was amplified using oligonucleotide primer templates specific for neuronal proPACAP mRNA (Table 1). Amplification with all three of the primer sets (PCP1/ PCP2, PCPX1/PCPX2, or PCPX5/PCPX6) produced the anticipated neuronal PACAP cDNA products. Using primers PCP1 and PCP2, PACAP precursor transcripts were identified when the amplified products from individual cardiac ganglia whole-mount preparations were separated by agarose gel electrophoresis and visualized with ethidium bromide staining (Fig. 2). Parallel amplification of cDNA from guinea pig superior cervical ganglia demonstrated that as in rat (Brandenburg et al., 1997), a population of the principal postganglionic neurons of guinea pig autonomic sympathetic ganglia also express proPACAP mRNA (data not shown). The amplified proPACAP fragments from cardiac ganglia were transferred subsequently to a nylon mem- 
Neuronal PACAP mRNA

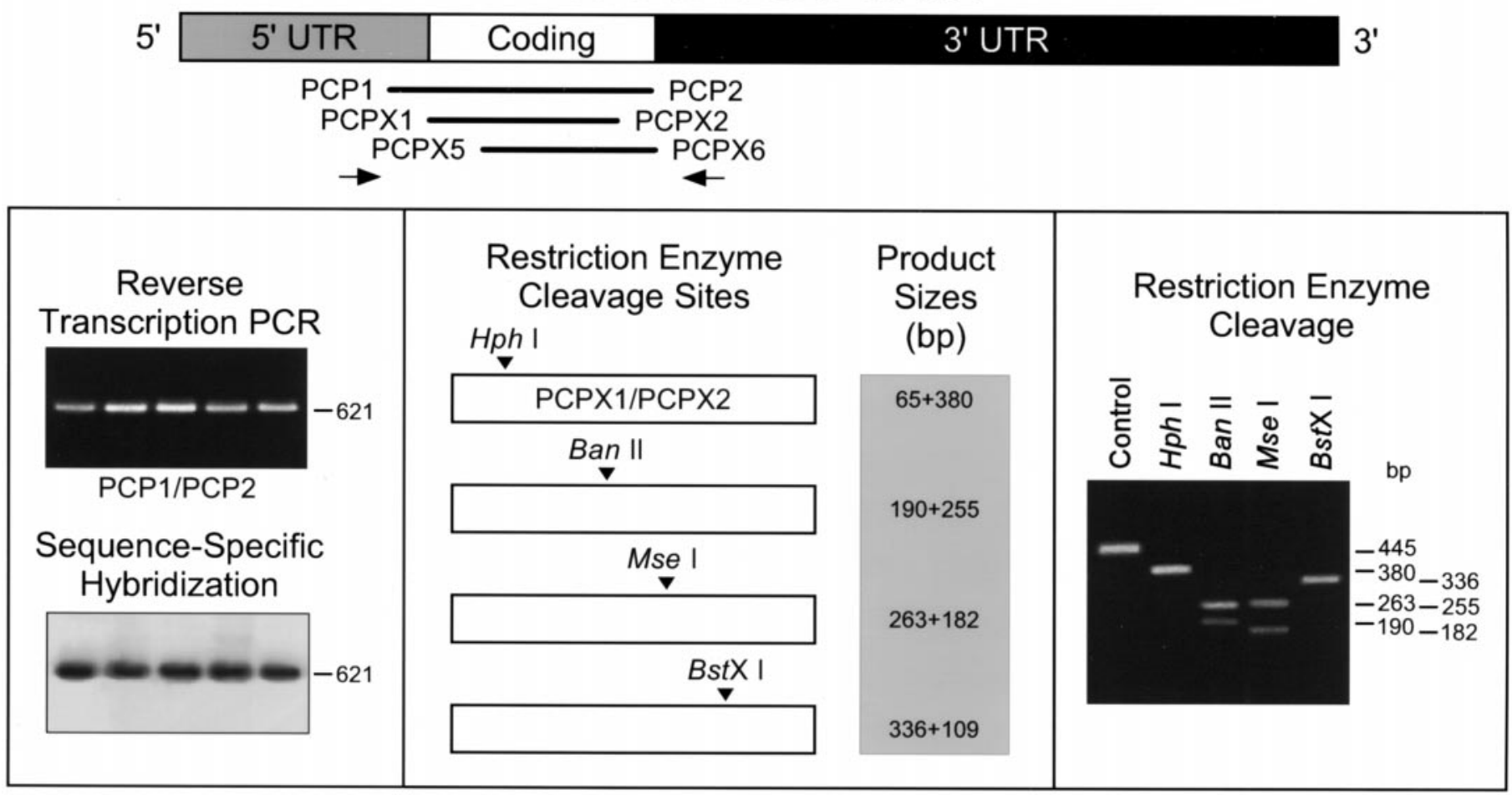

Figure 2. Cardiac ganglia express proPACAP mRNA. Total RNA from individual atrial cardiac ganglia preparations was reverse-transcribed, and each of three oligonucleotide primer sets spanning the proPACAP transcript coding region (schematic diagram, top) was used for PCR. The cDNA templates were amplified using primers PCP1 and PCP2, and the products were resolved on 1.6\% agarose gels, stained with ethidium bromide, and visualized by UV illumination. A single proPACAP band was produced (left panel, top). The identity of the RT-PCR product was substantiated using sequence-specific hybridization. When the proPACAP amplified products were transferred to Nytran and hybridized to a radiolabeled PACAP oligonucleotide probe internal to the primer sites, a single band of the appropriate size was identified (left panel, bottom). The 445 base pair product amplified using the primer pair PCPX1 and PCPX2 was isolated for diagnostic restriction analyses using Hph I, Ban II, Mse I, and BsfX I (center and right panels). The amplified products were digested with each enzyme for 4 or $16 \mathrm{~h}$, fractionated on agarose gels, stained, and examined under UV illumination. In each instance, digestion with endonuclease generated the predicted cleavage products. Control represents undigested amplified product. The schematic diagram is based on the rat neuronal proPACAP cDNA sequence reported by Ogi and coworkers (1990) (GenBank M63006). Gray, 5' untranslated region (5' UTR); white, coding region; black, 3' untranslated region (3' UTR); thick lines, regions amplified by the specified primers.

brane, and sequence-specific hybridization was performed with a radiolabeled oligonucleotide probe that recognized a sequence internal to the PACAP primers. Under stringent gene-specific hybridization and washing conditions, a single band of the expected size was produced, supporting the expression of PACAP transcripts by cardiac ganglia (Fig. 2).

To further identify the amplified products and characterize the guinea pig cardiac ganglia PACAP cDNA, the PCR fragments were recovered from the agarose gels for diagnostic restriction analyses, subcloning, and sequencing. After amplification with primers PCPX1 and PCPX2, restriction endonucleases selected to cleave at specific sites within the 445 base pair product corresponding to the segment of DNA spanning the translational initiation methionine through the first 13 amino acids of the PACAP peptides produced the pattern of cleavage fragments expected for the transcript (Fig. 2).

The 5' coding region amplified products obtained using PCPX1 and $\mathrm{PCPX} 2$, and the $3^{\prime}$ coding region amplified products obtained using primers PCPX5 and PCPX6, were subsequently subcloned and sequenced. Analyses of the cDNA encoding the guinea pig PACAP precursor protein demonstrated a high conservation of the nucleotide sequence compared with the rat, mouse, sheep, and human transcripts; nucleotide identity of the coding region of the guinea pig proPACAP cDNA was $84-87 \%$ compared with these species. The predicted proPACAP protein of guinea pig was composed of 180 amino acid residues, whereas the ovine and human sequences contained 176 amino acids, and the rat and mouse cDNA had 175 residues. Similar to the sheep and human proteins, the guinea pig precursor had one amino acid residue inserted at position 29; in contrast, only the guinea pig protein possessed a four amino acid insert in the highly variable region between the putative PACAP related peptide (PRP) and the PACAP peptides. Overall, the guinea pig preproPACAP exhibited $82-86 \%$ amino acid identity with the rat, mouse, sheep, and human proteins; the guinea pig precursor molecule had 93\% homology with the consensus sequence among these mammalian species. The region within the guinea pig transcript encoding the mature PACAP38 and PACAP27 peptides contained six to seven degenerate base substitutions ( $~ 94 \%$ nucleotide identity) compared with rat, mouse, ovine, and human, resulting in the preservation of all of the peptide amino acid residues (Fig. 3) (Ogi et al., 1990; Ohkubo et al., 1992; Okazaki et al., 1995). In addition, the dibasic amino acid post-translational endoproteolytic cleavage sites flanking the peptides as well as the amidation glycine residues were completely conserved among all of the species. These molecular studies determined the predicted amino acid sequence of the guinea pig PACAP peptides, further demonstrated the high conservation of the PACAP peptides among species, and impli- 


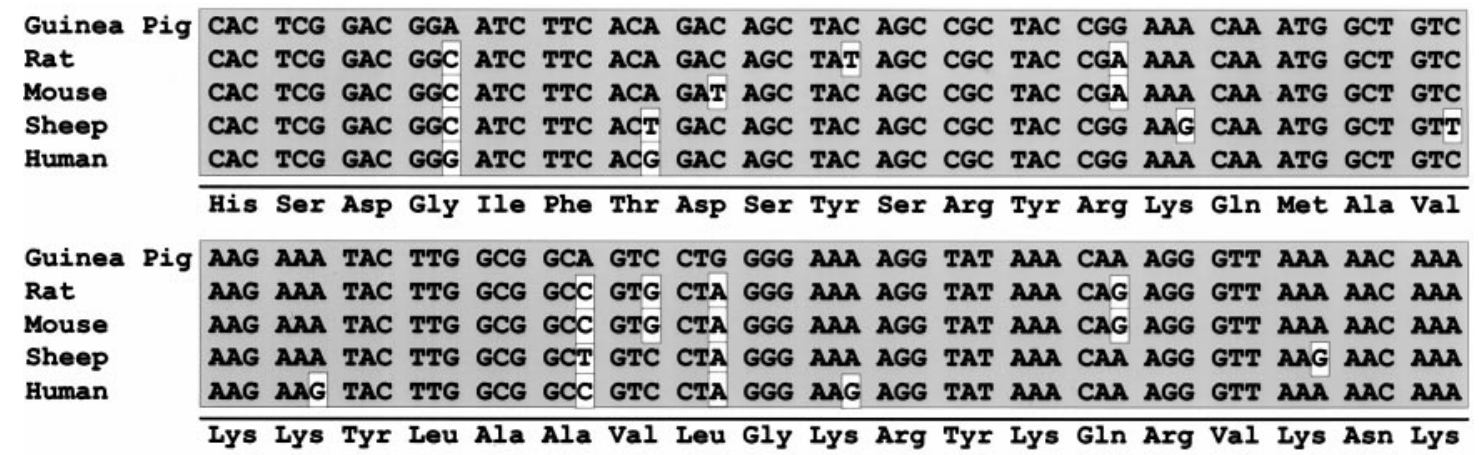

Figure 3. Guinea pig PACAP is homologous to other mammalian forms. Guinea pig cardiac ganglia cDNA was amplified with the oligonucleotide primer pairs PCPX1/PCPX2 and PCPX5/PCPX6. The products were purified, blunt-ended, and ligated into the pCR-Script cloning vector for transformation into competent cells. Automated fluorescence dideoxy dye terminator sequencing was performed in both directions using the T3 and T7 primer sites. The nucleotide sequence for the region of the guinea pig (cavia parcillus) transcript encoding the mature PACAP peptides is aligned with analogous regions of the rat [rattus norvegicus; Ogi et al. (1990); GenBank M63006], mouse [mus musculus; Okazaki et al. (1995); GenBank D14716], sheep (ovis aries; Ohkubo et al. (1992); GenBank S83511], and human [homo sapiens; Ohkubo et al. (1992); GenBank S83513) sequences. Nucleotides that differ from the guinea pig sequence are shown in white; regions of identity are shaded. The predicted amino acid sequences for the PACAP peptides are shown below. All base substitutions were degenerate, resulting in the conservation of all the amino acid residues encoding the PACAP peptides among species.

cated endogenous PACAP biosynthesis by a population of ganglia neurons.

\section{Cardiac ganglia neurons express multiple isoforms of the PAC1 receptor}

Three G-protein-coupled PACAP receptors (PACAP-selective PAC1 receptors and the nonselective VPAC1 and VPAC2 receptors) have been described, and the physiological responses of neuroendocrine cells to PACAP38, PACAP27, and VIP reflect the tissue-specific expression of these receptor subtypes (Spengler et al., 1993; Harmar and Lutz, 1994). Functional complexity also arises from the expression of PAC1 receptor splice variants resulting from alternative splicing within transcript regions encoding the amino terminal extracellular domain and the third cytoplasmic loop. The ligand high-affinity binding site resides in the amino terminal extracellular domain (Cao et al., 1995), and the presence or absence of a 21 amino acid (63 base pair) insert into the amino terminal segment has been suggested to alter PACAP27 and PACAP38 binding potencies (Pantaloni et al., 1996; Chatterjee et al., 1997). Alternative splicing of two 84 base pair (28 amino acid residue) HIP and/or HOP cassettes into the third cytoplasmic loop domain produces variants that exhibit differential patterns of cyclic AMP and inositol phosphate production by the two molecular forms of PACAP peptides (Spengler et al., 1993). Previous studies suggest that pharmacologically, parasympathetic cardiac neurons express PAC1 receptors (Seebeck et al., 1996). Accordingly, to understand the functional relevance and prevalence of the different PAC1 receptor isoforms in cardiac ganglia, expression of PAC1 receptor splice variants was examined by RT-PCR.

Sets of oligonucleotide primer templates were designed to flank the DNA segments corresponding to the alternatively spliced exons in the amino terminal extracellular domain (PACAPRX3/ PACAPRX4) (Table 1) and third cytoplasmic loop (PACAPR1/ PACAPR2) (Table 1) of the PAC1 receptor (Spengler et al., 1993; Pantaloni et al., 1996). The amplified products from these primer sets therefore not only indicated tissue PAC1 receptor mRNA expression but also were diagnostic of the receptor isoforms expressed by the cardiac neurons, providing insights into potential differences in peptide potency and receptor coupling to multiple intracellular signaling cascades.
RT-PCR of cardiac ganglia total RNA with either of these primer sets identified PAC1 receptor expression in the guinea pig atrial preparations (Figs. 4, 5). The presence or absence of exons 4 (21 nucleotides) (Chatterjee et al., 1997) and 5 (42 nucleotides) of the PAC1 receptor gene [numbered as exons 5 and 6 by Pantaloni et al. (1996)], resulting in the insertion or deletion of a 21 amino acid segment in the amino terminal extracellular domain, produces the short and very short receptor variants, respectively. Amplification using primers PACAPRX3 and PACAPRX4, which flank the amino terminal alternative splice site of exons 4 and 5, produced a prominent 447 base pair amplified product, suggesting that the cardiac ganglia expressed predominantly the very short PAC1 receptor variant (Fig. 4). A larger, 510 base pair product that appeared to correspond to the short receptor isoform containing the alternatively spliced exons 4 and 5 was also present, but at much lower levels. Restriction endonuclease digestion of the predominant 447 base pair product yielded the cleavage pattern expected for the region of the PAC1 receptor cDNA without the 63 base pair insert; neither $P f \mathrm{~F}$ I, which requires an intact exon 3 and 4 border for cleavage, nor Tsp509 I, which cleaves within exon 5, digested the amplified receptor cDNA fragment (Fig. 4). Because this amplified segment of receptor DNA results from the splicing of several exons, the 447 base pair PCR product was subcloned and sequenced to confirm that the observed receptor transcript resulted from the expected alternative exon usage. The sequence data verified that the major guinea pig transcript represented the very short receptor variant, lacking both exons 4 and 5. This region of amplified receptor cDNA exhibited $86-90 \%$ nucleotide identity to the rat, mouse, cow, and human sequences; the guinea pig fragment had $92 \%$ identity with the consensus sequence among the various species. The predicted amino acid sequence of the guinea pig receptor segment displayed 90-93\% identity to the deduced residues present in the receptor proteins from other species. Other studies demonstrated that most neuronal tissues exhibit the short receptor variant (Pantaloni et al., 1996; K. Braas and V. May, unpublished results); consequently, this tissue-specific expression of the very short PAC1 receptor variant in cardiac ganglia may be unique.

Amplification of the templates using the primers PACAPR1 and PACAPR2 revealed that the cardiac neurons also expressed 
PAC1 Receptor mRNA
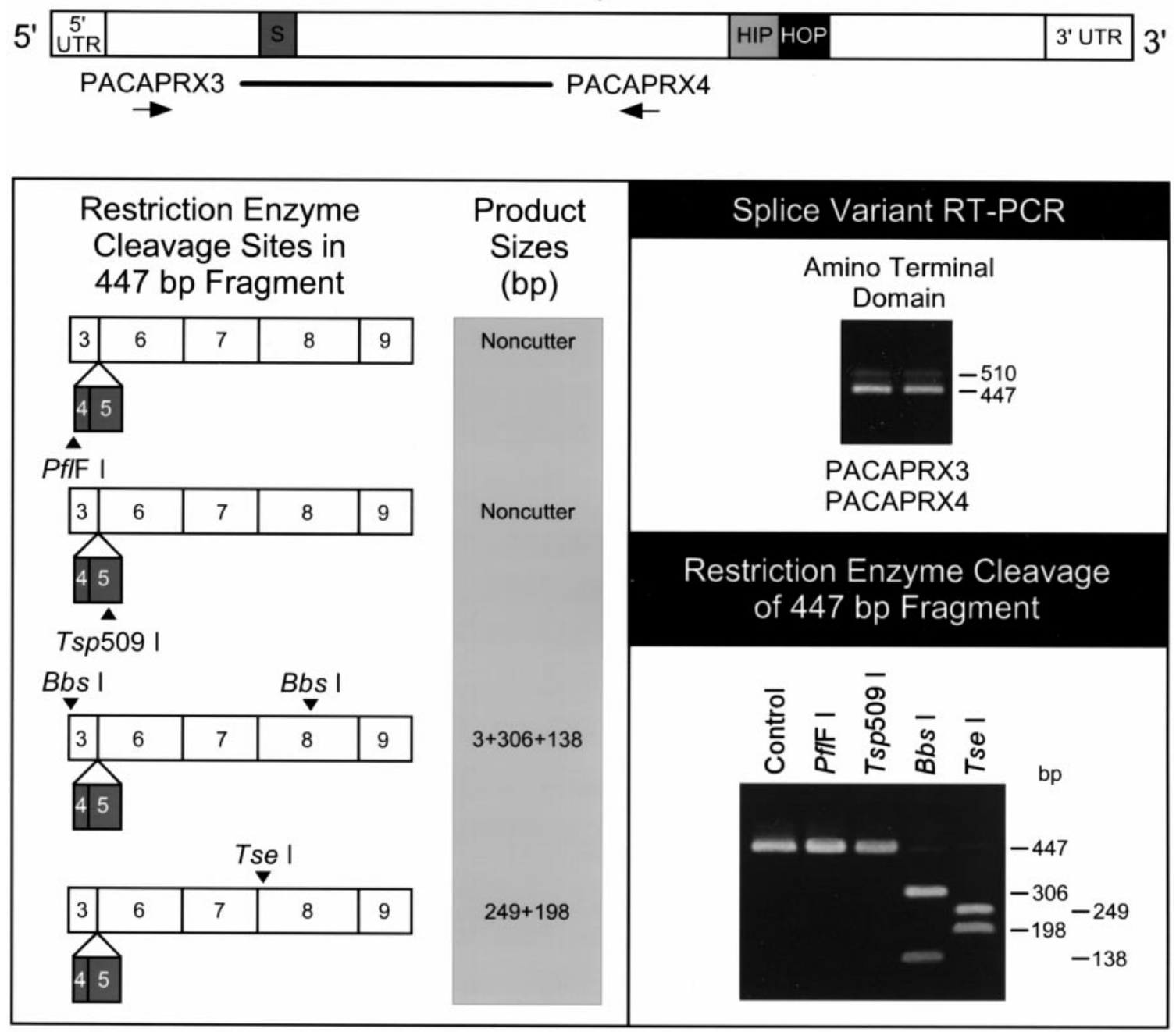

Figure 4. Cardiac ganglia express the very short PAC1 receptor isoform. Complementary DNA templates were reverse-transcribed from guinea pig atrial cardiac ganglia tissue total RNA, and a segment spanning the extracellular amino terminal splice sites of the PAC1 receptor mRNA was amplified using primers PACAPRX3 and PACAPRX4 (schematic diagram, top). The prominent amplified product was 447 base pairs in size corresponding to the very short isoform of the PAC1 receptor, which does not contain exon 4 (21 nucleotides) and exon 5 (42 nucleotides) (right panel, top). The 510 base pair product corresponding to the short variant containing the two alternatively spliced exons was lower in abundance. The 447 base pair amplified product was recovered from 1.6\% agarose gels for diagnostic restriction analyses with a panel of enzymes (left panel). Enzymes PflF I and Tsp509 I, with sites unique to the short receptor variant, failed to cleave the 447 base pair product. Endonuclease digestion of the product with $B b s$ I or Tse I yielded the anticipated fragments for the region of the PAC1 receptor cDNA without the 63 base pair insert (left panel; right panel, bottom). Control is the undigested amplified 447 base pair product. The mRNA schematic diagram is based on the rat PAC1 receptor sequence [Spengler et al. (1993); GenBank Z23272]. Dark gray, Short region containing exons 4 and 5; light gray, HIP cassette; black, HOP cassette; thick line, region amplified using PACAPRX3 and PACAPRX4. Numbers in the schematic diagram of the restriction enzyme cleavage sites in the 447 bp fragment refer to the regions of the exons represented in the product (Chatterjee et al., 1997).

multiple receptor isoforms resulting from alternative splicing of exons into the region of the transcript encoding the third cytoplasmic loop (Fig. 5). The predominant 303 base pair product corresponded to the receptor variant containing neither the HIP nor HOP cassettes. The identity of the amplified product was verified by restriction analyses using $S f a \mathrm{~N}$ I, Hae III, or HinF I, which produced the expected endonucleolytic cleavage fragments (Fig. 5). Expression of the message encoding the PAC1 receptor isoform containing one cassette was lower. To identify the one cassette variant, the fragment was subcloned and sequenced. From eight clones sequenced in both directions, this guinea pig cardiac ganglia PACAP-selective receptor splice variant corresponded to the rat HOP receptor isoform; furthermore, all of the clones were the shortened HOP2 variant containing 384 nucleotides (Fig. 6). In rat, alternative usage of contiguous splice acceptor sites in the HOP cassette produces either the 387 nucleotide HOP1 or 384 nucleotide HOP2 variants (Spengler et al., 1993); accordingly, these results suggested that similar splicing events generate the PACAP receptor $\mathrm{HOP} 2$ variant in guinea pig cardiac ganglia. The sequence of the HOP2 isoform previously identified only in rat varied in the guinea pig by only one nucleotide, resulting in a degenerate codon for the same leucine residue. The same nucleotide substitution was observed in the bovine HOP1 variant (Miyamoto et al., 1994). The predicted amino acid sequence was identical for the guinea pig, rat, mouse, and cow HOP cassettes (Fig. 6) (Hashimoto et al., 1993, 1996; Hosoya et al., 
PAC1 Receptor mRNA
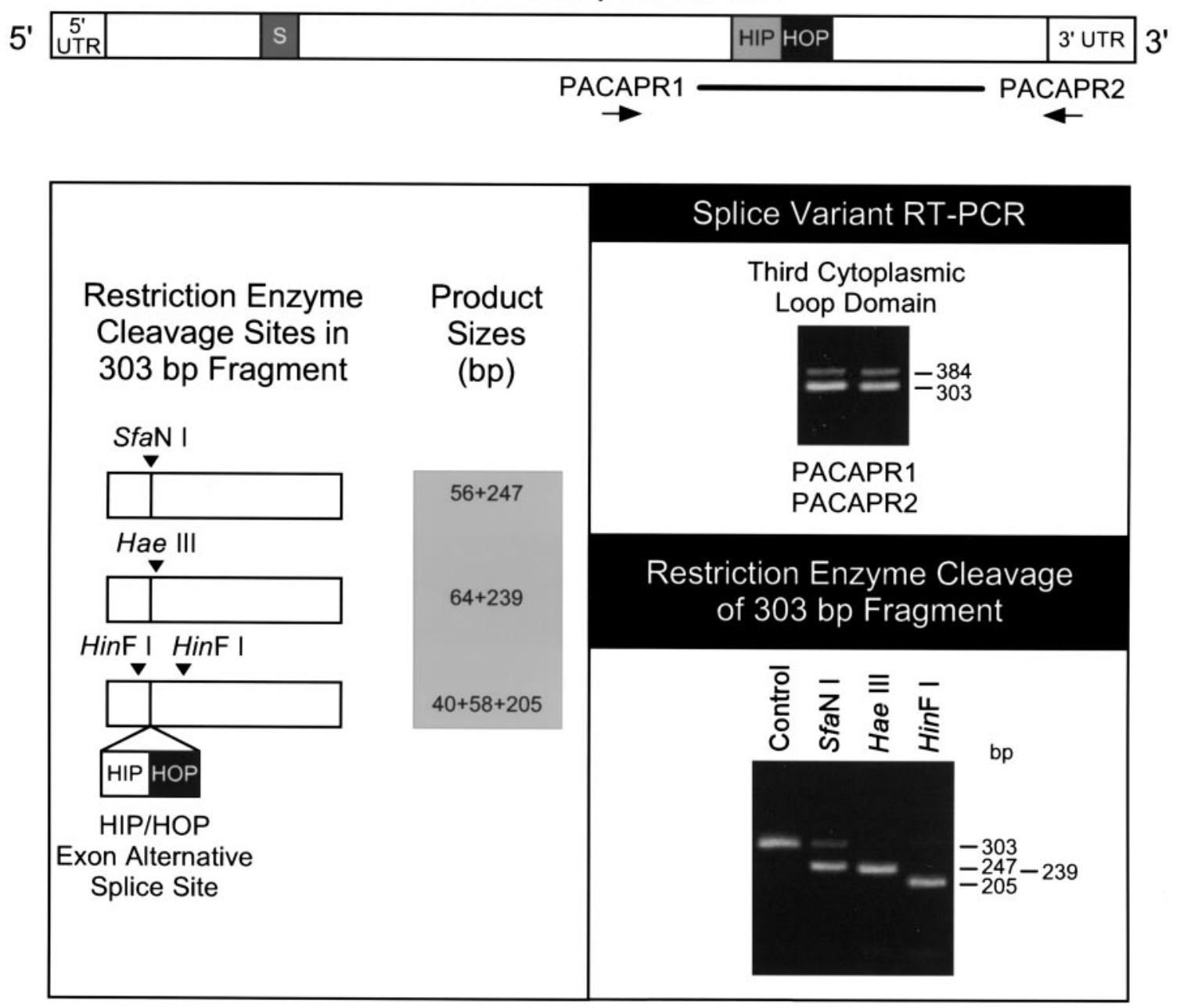

Figure 5. PAC1 receptor variants in cardiac ganglia also result from alternative splicing within transcript regions encoding the third cytoplasmic loop. Reverse-transcribed cDNA templates from guinea pig atrial cardiac ganglia preparation RNA were used for PCR using primers PACAPR1 and PACAPR2, which span a segment of the PAC1 receptor transcript corresponding to the alternative splice site for the HIP and HOP cassettes within the third cytoplasmic loop (schematic, top). Two products were amplified: the predominant 303 base pair product corresponded to the receptor with neither the HIP nor HOP cassettes, whereas the 384 base pair product represented a one-cassette receptor variant (right panel, top). The 303 nucleotide product was isolated for diagnostic restriction endonuclease digestion with SfaN I, Hae III, or HinF I. The resulting enzymatic cleavage products corresponded to the predicted fragments for the receptor variant without either cassette (left panel; right panel, bottom). Control represents the undigested amplified 303 base pair product. The receptor mRNA schematic is described in Figure 4. Thick line, Region amplified using PACAPR1 and PACAPR2.

1993; Spengler et al., 1993; Miyamoto et al., 1994). This high level of both nucleotide and amino acid conservation among species suggests that the sequence encoded by the HOP exon may be critical to the function of the PAC1 receptor isoform. The entire 384 base pair amplified region of the guinea pig cDNA, which encompasses both the 303 nucleotide fragment and the alternatively spliced HOP2 cassette, exhibited a high degree of nucleotide homology with the other reported PAC1 receptor sequences. The guinea pig PACAPR1/PACAPR2 product demonstrated 92$94 \%$ identity to the rat, mouse, and cow receptor transcripts. The reported human receptor sequence does not contain either the HIP or HOP exons, but the alternative 303 nucleotide fragment exhibited $92 \%$ identity to the corresponding guinea pig sequence (Ogi et al., 1993). Interestingly, the deduced amino acids encoded by the entire fragment amplified using the PACAPR1 and PACAPR2 primers are identical among the various species except for one conservative valine to isoleucine substitution at residue 95
(HOP2 numbering) of the guinea pig, and alanine and valine substitutions at positions 123 and 124 of the human sequence.

These results demonstrated that alternative splicing of the PAC1 receptor transcripts encoding uncommon variants appear to be produced in cardiac ganglia. The predominant receptor isoform expressed is expected to be the very short variant with neither the HIP nor HOP cassettes; expression of short and HOP2 variants are suggested to be much lower. The absence of the 21 amino acid segment in the amino terminal extracellular domain of the very short receptor may have significant implications in PACAP27 and PACAP38 binding and potency. Alternative splice variants in the region of the third cytoplasmic loop, which is important for G-protein coupling, exhibit specific patterns of cyclic AMP and inositol phosphate production. How the presence of neither cassette or the HOP2 cassette in cardiac neuron PACAP-selective receptors transduces downstream intracellular signaling remains to be established. 


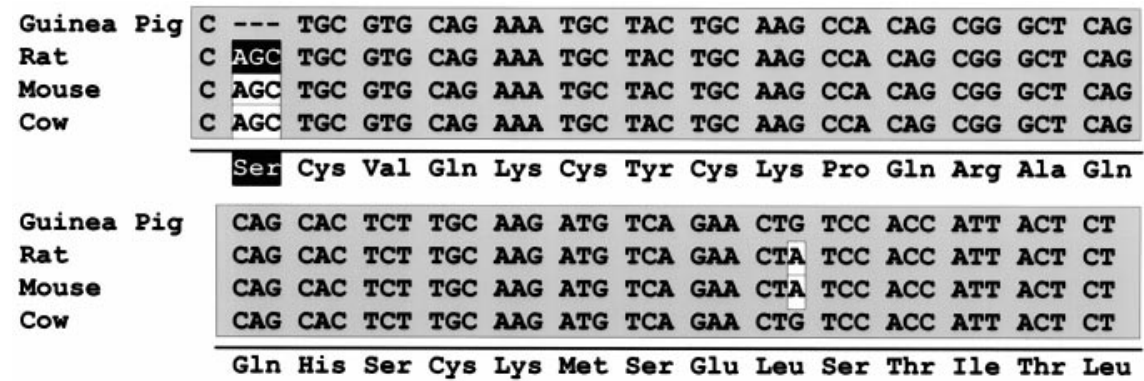

Figure 6. The alternatively spliced PAC1 receptor isoform containing one cassette in the third cytoplasmic loop represents the HOP2 variant. The guinea pig PACAP-selective receptor 384 base pair product amplified using the PACAPR1 and PACAPR2 primers (see Fig. 4) was isolated and subcloned for automated fluorescence dideoxy dye terminator sequencing. All of the clones represented the HOP variant shortened at the alternative splice junction, consistent with the expression of the HOP2 form reported in rat (Spengler et al., 1993). The base sequence for the guinea pig (cavia parcillus) HOP2 cassette is aligned with the HOP1 sequences reported for the corresponding regions of the rat [rattus norvegicus; Spengler et al. (1993); GenBank Z23275 and Z23274], mouse [mus musculus; Hashimoto et al. (1996); GenBank D82935], and cow (bos taurus; Miyamoto et al. (1994); GenBank D17290]). Nucleotides differing from the guinea pig sequence are in white; regions of identity are shaded with gray. The three nucleotides deleted from the HOP2 isoform encoding a serine residue in the HOP1 variant of the rat, produced by alternative usage of contiguous splice acceptor site, are shaded with black. The predicted amino acid residues for the HOP PACAP receptor variant are shown below the nucleotide sequences. The one-base substitution is degenerate and conserves the leucine residue.
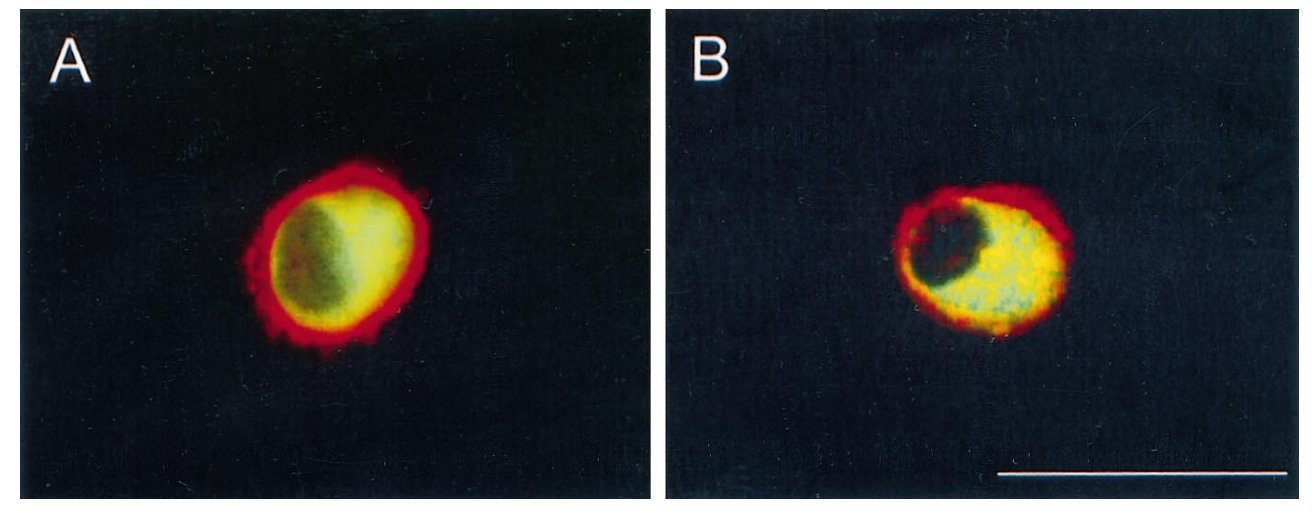

Figure 7. PAC1 receptor protein immunoreactivity is localized to cardiac ganglia neuronal plasma membranes. $A, B$, Dissociated cardiac ganglia neurons were immunocytochemically processed for $\mathrm{PAC} 1$ receptor $(\mathrm{Cy} 3$, red $)$ and MAP-2 (FITC, green) and imaged under confocal microscopy. Plasma membrane labeling for the PAC1 receptor circumscribed the MAP-2-positive cardiac neurons. Scale bar, $50 \mu \mathrm{m}$.

\section{PAC1 receptor protein is localized to cardiac neurons}

The molecular analyses implicated PAC1 receptor isoform expression in cardiac neurons; however, the sites of these PACAPselective receptors in the ganglia preparation were unclear. To identify the cellular localization and prevalence of PAC1 receptor protein expression in cardiac ganglia, immunocytochemical studies were performed using antiserum directed against a segment in the amino terminus of the receptor common to all isoforms. Similar to the dual-labeling immunocytochemical studies examining PACAP peptide expression in cardiac ganglia neurons, antiserum to MAP-2 was used to identify unequivocally cardiac neurons in the atrial preparation. Essentially, all of the MAP-2positive neurons in intact whole-mount preparations and acutely dissociated cardiac neurons expressed PACAP receptor immunoreactivity, whereas no staining was observed in either method or absorption control samples (data not shown). Using confocal microscopy, staining for the PAC1 receptor was observed circumscribing the neuronal plasma membrane (Fig. 7A, $B$ ).

\section{PACAP27 depolarizes guinea pig cardiac neurons}

To complement the morphological and molecular approaches, electrophysiological studies were performed to examine the direct actions of PACAP peptides on guinea pig cardiac neurons. The majority of the neurons in the guinea pig cardiac ganglia are phasic, initiating one to two action potentials during long depolarizing current pulses. In contrast, only a few cells are tonic, firing trains of action potentials on stimulation (Adams and
Harper, 1995; Akasu and Nishimura, 1995; Edwards et al., 1995; Hardwick et al., 1995). Consistent with the immunocytochemical studies, nearly all of the cardiac neurons responded to PACAP. Electrophysiological recordings from $>50$ individual neurons in 20 different atrial preparations demonstrated that $88 \%$ of the neurons responded to PACAP27. Local pressure application of PACAP27 $(50 \mu \mathrm{M}, 1 \mathrm{sec}$ at $\sim 7 \mathrm{psi})$ to individual neurons produced a $7 \pm 0.7 \mathrm{mV}$ depolarization ( $n=11$ neurons; mean resting potential was $-51 \pm 2.8 \mathrm{mV}$ ). The duration of the depolarization varied from 10 to $40 \mathrm{sec}$ among neurons. In one-third of the neurons tested, a burst of action potentials occurred during the initial period of depolarization, which subsided before repolarization (Fig. 8A1, $A 2$ ). This increase in action potential frequency was observed in both phasic (Fig. 8A1) and tonic cells (Fig. 8A2). Although an increase in action potentials was not produced during the PACAP-induced depolarization in the remaining neurons, PACAP27 increased the membrane excitability of all of these cells. After application of PACAP27 to the remaining population of phasic neurons, multiple action potentials were elicited in response to a $500 \mathrm{msec}$ suprathreshold depolarizing current pulse, which would normally produce one to two action potentials (data not shown). The PACAP-induced increase in membrane excitability was of long duration, lasting for minutes after pressure application of peptide.

To ensure that the ability of PACAP27 to depolarize the cardiac neurons resulted from a direct action on the neurons 

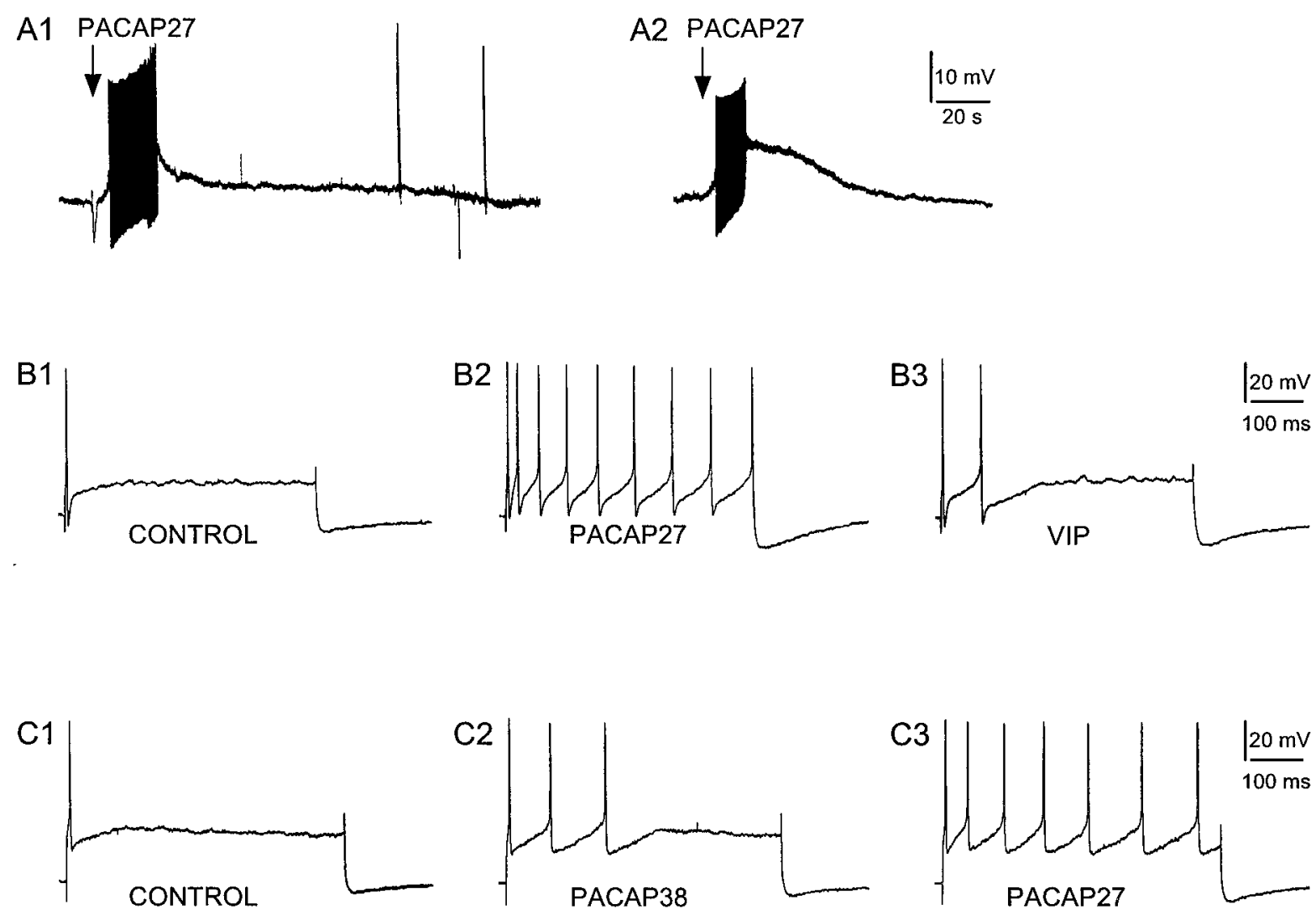

Figure 8. PACAP induces depolarization and increases membrane excitability of cardiac ganglia neurons. Local application of PACAP27 (50 $\mu \mathrm{M}, 1 \mathrm{sec})$ depolarized both phasic $(A 1)$ and tonic $(A 2)$ cardiac neurons. A $500 \mathrm{msec}$ depolarizing current pulse $(B, 0.3 \mathrm{nA} ; C, 0.4 \mathrm{nA})$ to cardiac neurons typically elicited a single action potential $(B 1, C 1)$. Superfusion of the same neurons with $100 \mathrm{nM}$ PACAP27 increased membrane excitability under the same depolarizing conditions $(B 2, C 3)$. In this example, three spikes were elicited after 100 nm PACAP38 application $(C 2)$. After a 10 min recovery, the same cell superfused with $100 \mathrm{nM}$ PACAP27 produced seven spikes under an identical depolarizing current pulse (C3). In a comparable experimental paradigm, the changes in neuronal excitability were compared between $100 \mathrm{~nm}$ PACAP27 and $100 \mathrm{nM}$ VIP. Nine spikes were elicited after PACAP27 application (B2), whereas only two action potentials were elicited by VIP application in the same neuron after an $\sim 25$ min wash (B3). Additional experiments indicated that $100 \mathrm{~nm}$ VIP produced few or no changes in excitability. In all cases, PACAP27 was more effective than the same concentrations of VIP (B3) or PACAP38 (C2). Data are representative of four to five neurons for each treatment paradigm.

rather than an induction of neurotransmitter or neuropeptide release from adjacent nerve terminals, the effects of PACAP27 were also determined under conditions that blocked release. In cardiac ganglia whole-mount preparations bathed in either calcium-deficient solution containing $300 \mathrm{nM}$ tetrodotoxin or Krebs' solution with $200 \mu \mathrm{M}$ cadmium, PACAP27 depolarized all of the neurons $\sim 5 \pm 0.3 \mathrm{mV}$ (mean resting potential was $-55 \pm$ $4.0 \mathrm{mV}$ ). These results indicated that the PACAP-induced depolarization resulted from direct peptide actions on the parasympathetic neurons.

PACAP did not produce any consistent changes in neuronal input resistance. In four sympathetic neurons examined either by superfusion with $100 \mathrm{~nm}$ PACAP27 or pressure application of 50 $\mu \mathrm{M}$ peptide, the mean input resistance decreased $3.0 \pm 3.8 \%$.

\section{PACAP27 increases cardiac ganglion neuron membrane excitability}

PACAP peptides are 100- to 1000 -fold more potent than VIP in eliciting neuronal responses at the PACAP-selective receptor than at either of the nonselective VPAC1 and VPAC2 receptors (Spengler et al., 1993; Harmar and Lutz, 1994; Rawlings, 1994; Journot et al., 1995; May and Braas, 1995; Rawlings and Hezareh, 1996). To examine the relative potencies of the PACAP and VIP peptides and infer from the neuropharmacological profiles the
PACAP/VIP receptor subtypes involved in the parasympathetic postganglionic neuron physiological responses, studies were performed using superfusion application of PACAP27, PACAP38, or VIP. Depolarization was induced in nearly all neurons superfused with PACAP; however, with subsequent applications, the amplitude of the depolarization was diminished or absent. In contrast, PACAP increased neuronal excitability in almost all of the neurons $(>85 \%)$ regardless of measurable PACAP-induced depolarization. Accordingly, subsequent electrophysiological experiments quantitated the PACAP-induced increase in membrane excitability. The changes in membrane excitability for phasic neurons were established by determining the number of action potentials produced by $500 \mathrm{msec}$ suprathreshold depolarizing current pulses of increasing magnitude. Excitability was tested before and immediately after a $30 \mathrm{sec}$ superfusion with peptide. Initially, the effects of superfusion of atrial whole-mount preparations with $100 \mathrm{~nm}$ PACAP27, PACAP38, or VIP were compared. As expected, PACAP27 increased excitability, whereas VIP had little or no effect (Fig. $8 B$ ). Surprisingly, PACAP27 appeared more effective in increasing excitability than PACAP38 (Fig. $8 C$ ); the peptides demonstrated an apparent rank order of stimulation of PACAP27 $>$ PACAP38 $>$ VIP.

To establish the concentration dependence of the PACAP- 

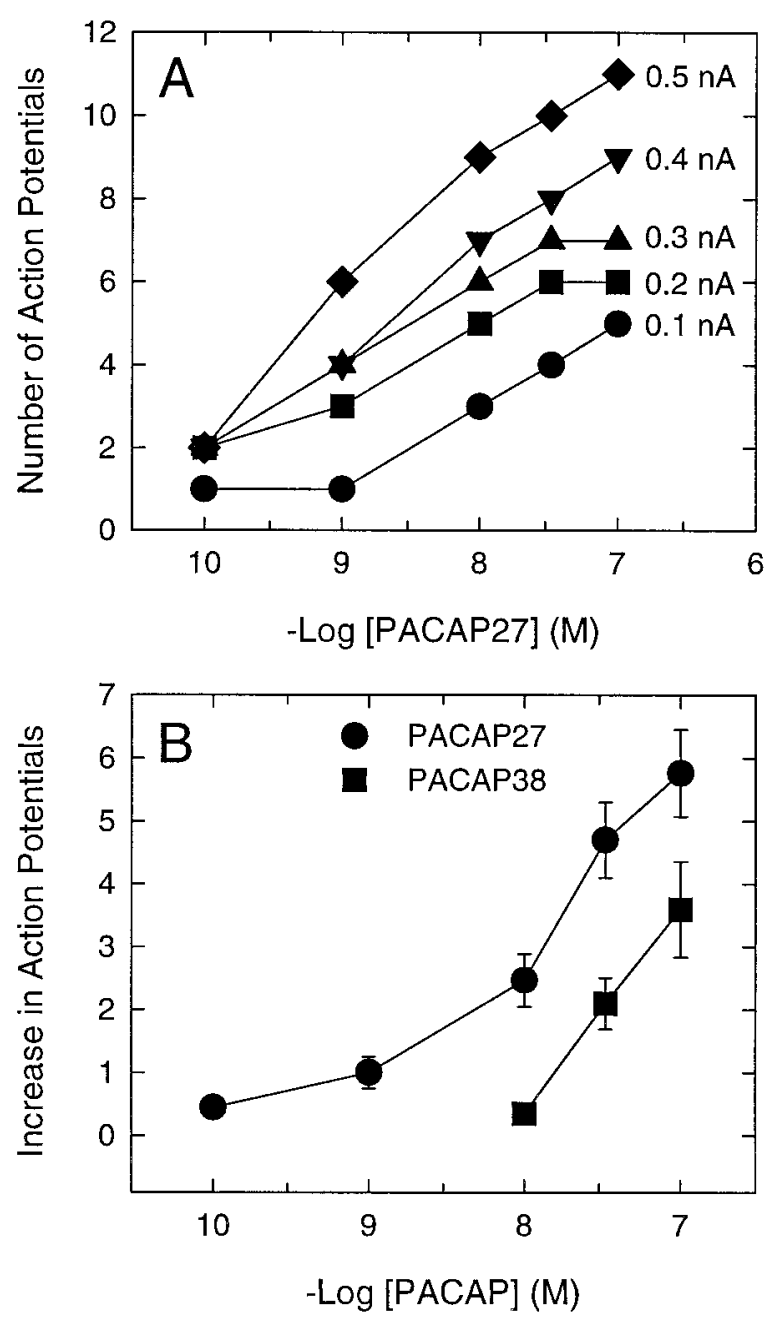

Figure 9. The PACAP-induced increase in cardiac neuron membrane excitability is concentration dependent. $A$, The number of action potentials elicited by $500 \mathrm{msec}$ depolarizing current pulses of increasing intensity (0.1-0.5 nA) was augmented with increasing concentrations of superfused PACAP27 (0.1-100 nM peptide). $B$, The concentration dependence of increased membrane excitability in response to PACAP27 or PACAP38 superfusion was examined by determining the number of action potentials produced by increasing stimulus intensities $(0.1-0.5 \mathrm{nA} ; 500 \mathrm{msec}$ duration).

induced increase in excitability, the effects of different concentrations of PACAP27 or PACAP38 on individual neurons were determined. At each peptide concentration, the number of action potentials generated by depolarizing current pulses of increasing strengths was determined. As expected for phasic cells, only one action potential typically was produced before peptide application, regardless of the current intensity (0.1-0.5 nA). However, after PACAP peptide application, multiple spikes were elicited. The number of action potentials was dependent on stimulus intensity, peptide, and agonist concentration. For example, in a representative experiment, a phasic neuron was superfused with each concentration of PACAP27 for $30 \mathrm{sec}$. After each peptide application, a series of $500 \mathrm{msec}$ current pulses ranging from 0.1 to $0.5 \mathrm{nA}$ was delivered to the cell. The neuron was washed between peptide applications until only one action potential was produced by the current pulse, to ensure recovery from peptide exposure. As shown in Figure $9 A$, in which the number of action potentials produced with the different current pulse intensities is

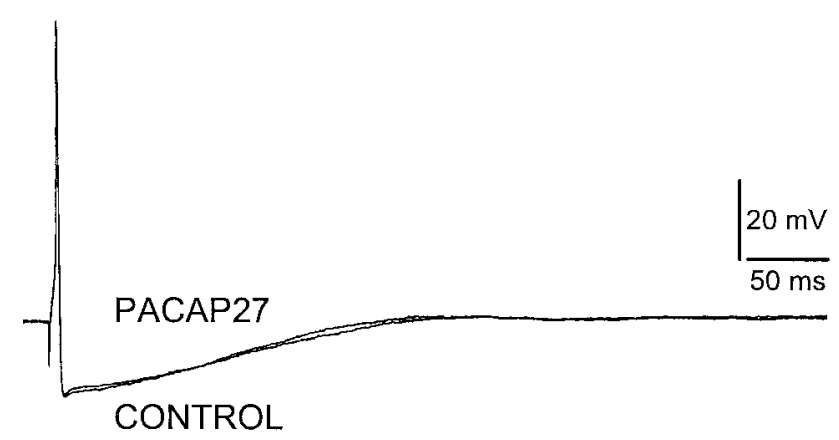

Figure 10. PACAP27 does not alter cardiac neuron action potential characteristics. Five action potentials produced by depolarizing current pulses $(0.3 \mathrm{nA}, 5 \mathrm{msec})$ were collected before and after neuron superfusion with $100 \mathrm{~nm}$ PACAP27. Traces are the average of five action potentials. The resting potential was $-47 \mathrm{mV}$. Action potential configuration was similar before and during PACAP exposure. PACAP increased excitability in the neuron shown in this example. Data are representative of four neurons.

expressed as a function of the peptide concentration, PACAP27 produced a concentration-dependent increase in neuronal membrane excitability. The concentration dependence for PACAP27 and PACAP38 was compared among neurons (Fig. 9B). PACAP27 was more potent than PACAP38 in increasing membrane excitability. PACAP27 exhibited an estimated $\mathrm{EC}_{50}$ of $<20$ nM, whereas PACAP38 was approximately fourfold less potent. These physiological studies of guinea pig cardiac ganglia were consistent with the premise that the PACAP effects were mediated through PACAP-selective receptors rather than either of the nonselective VIP/PACAP receptors.

The observation that the PACAP-induced increase in excitability occurred in the absence of membrane depolarization suggested that depolarization per se was not responsible for this effect. Consequently, studies were conducted to determine whether the increases in excitability could be attributed to changes in action potential properties such as the hyperpolarizing afterpotential (HAP). Action potentials were elicited by brief supramaximal current pulses sufficient to elicit single spikes preceding and following superfusion with $100 \mathrm{~nm}$ PACAP27 for 15-30 sec. PACAP peptide did not alter action potential characteristics of the cardiac neurons (Fig. 10), indicating that the increase in excitability was not correlated with a PACAP-induced change in action potential configuration.

\section{DISCUSSION}

PACAP peptides have extraordinarily diverse neuroregulatory and neurotrophic roles in the peripheral nervous system (Arimura et al., 1994; May and Braas, 1995; DiCicco-Bloom, 1996; Sundler et al., 1996; Tanaka et al., 1996; Cardell et al., 1997; Lu and DiCicco-Bloom, 1997; Mirfendereski et al., 1997; Villalba et al., 1997). Among these effects, recent studies have demonstrated PACAP-induced bradycardia in isolated atrial tissues, suggesting a role for these peptides in the control of acetylcholine release from parasympathetic neurons (Seebeck et al., 1996; Hirose et al., 1997). Many neuropeptides and factors have been postulated to participate in cardiac ganglia function; accordingly, PACAP peptides may represent one of several potent modulators of the parasympathetic response.

Several key criteria must be established to demonstrate neuronal PACAP-specific regulation of parasympathetic postganglionic neurons in the cardiac ganglion, including the following: (1) 
PACAP peptide expression must be localized to fiber tracts and/or neurons within the ganglia; (2) cardiac ganglia must express the PACAP-selective PAC1 receptor; and (3) PACAP peptides must elicit direct physiological effects on cardiac neurons with a pharmacological profile that is PACAP-selective. The present studies were conducted to examine these requisites.

Both PACAP immunoreactivity and mRNA were demonstrated in the cardiac ganglion preparations. RT-PCR and related diagnostic analyses demonstrated PACAP mRNA expression in the cardiac ganglia tissue samples, implicating the potential for endogenous PACAP peptide biosynthesis. Molecular analyses of guinea pig proPACAP cDNA demonstrated that the predicted amino acid sequences of the mature PACAP peptides were identical to the human, rat, mouse, and sheep sequences, which was consistent with the strict evolutionary conservation of PACAP peptides (Ogi et al., 1990; Okhubo et al., 1992; Okazaki et al., 1995). Parallel immunocytochemical studies identified a small population of intrinsic PACAP-immunoreactive neurons in the whole mounts; $<5 \%$ of the cholinergic cardiac postganglionic neurons expressed PACAP, suggesting that these peptides may be present in interneurons with neuromodulatory roles in cardiac ganglia function (Konopka et al., 1992; Hardwick et al., 1995; Mawe et al., 1996).

By far, the most striking pattern of PACAP immunoreactivity was present in intraganglionic fibers. Although the sources of these extrinsic PACAP immunoreactive fibers have not been established, the staining patterns were distinct from previous neuropeptide immunocytochemical studies in many respects. In atrial whole-mount studies examining the distribution of sensory substance P- and CGRP-immunoreactive afferents, and sympathetic postganglionic neuropeptide $\mathrm{Y}$-containing processes, the fiber staining patterns were not only intraganglionic but also were distributed densely over the tissue to innervate vessels and myocardium (Konopka et al., 1992; Hardwick et al., 1995; Kennedy et al., 1998). Because PACAP-immunoreactive fibers were not observed to extend into adjacent atrial tissue, these neuronal processes were most likely not sensory afferents or sympathetic postganglionic fibers. However, the PACAP fiber staining patterns did compare favorably with those for choline acetyltransferase in parasympathetic preganglionic fibers. Several previous studies have demonstrated PACAP-immunoreactivity in cholinergic fibers. PACAP was colocalized with choline acetyltransferase in splanchnic nerves, in preganglionic projection neurons to the superior cervical ganglion, and in parasympathetic preganglionic fibers in salivary gland (Tobin et al., 1995; Holgert et al., 1996; Beaudet et al., 1998). Furthermore, PACAPimmunoreactive neurons have been identified in brainstem medullary areas (Legradi et al., 1994; Lai et al., 1997) and are thought to contribute vagal fibers into the heart. In sum, these results suggested that the PACAP immunoreactivity in the cardiac ganglion fiber plexuses may be both intrinsic from PACAPcontaining cardiac neurons and extrinsic from vagal parasympathetic preganglionic inputs. The relative contribution of these two sources of PACAP in the maintenance and regulation of cardiac function remains to be established. Because ganglionic neuronal PACAP levels can be regulated by neuronal activity or injury (Zhang et al., 1995; May et al., 1996; Brandenburg et al., 1997; Moller et al., 1997), the intrinsic sources of PACAP may have more prominent roles during altered cardiovascular states.

Of equal import, these studies also demonstrated the expression of PACAP-selective receptors in cardiac ganglia neurons. Given the insensitivity of guinea pig cardiac neurons to VIP, the responses appear to be mediated by neither of the PACAP/VIP nonselective VPAC1 or VPAC2 receptors, but by the PACAPselective G-protein-coupled PAC1 receptor. Alternative splicing of the transcripts in the regions encoding the extracellular amino terminal domain and the third cytoplasmic loop generate multiple isoforms of the PAC1 receptor, which were previously shown to exhibit differential patterns of peptide binding and coupling to intracellular signaling (Spengler et al., 1993; Pantaloni et al., 1996). Analyses of the amplified PCR products for the PACAPselective receptor demonstrated expression of atypical PAC1 receptor variants in the cardiac ganglia preparations. The predominant PAC1 receptor in the cardiac ganglia appeared to be the very short PAC1 variant with neither HIP nor HOP cassette inserts into the third cytoplasmic loop. The amino terminal extracellular domain of the VIP/PACAP family of receptors is characteristically long, and the 21 amino acid segment $\left(\mathrm{Val}^{89}\right.$ to Ser ${ }^{109}$ ) encoded by the 63 nucleotides resulting from splicing of exons 4 and 5 into the PAC1 receptor mRNA lies within the receptor domain implicated in ligand binding (Cao et al., 1995; Couvineau et al., 1995). Because the segment is strongly acidic and postulated to impair PACAP27 binding (Pantaloni et al., 1996), the absence of these 21 amino acids in the guinea pig very short PAC1 receptor may contribute to the observed differences in PACAP27 and PACAP38 potencies in neuronal membrane excitability. Both PACAP27 and PACAP38 elicited concentration-dependent increases in membrane excitability with halfmaximal responses in the nanomolar range, but the apparent pharmacological rank order of potency for the peptides (PACAP27 $>$ PACAP38 $>$ VIP) is consistent with the expression of specific PAC1 receptor variants in the postganglionic neurons. Because the predicted amino acid sequences for guinea pig PACAP27 and PACAP38 are identical to that reported for other mammals, the differences in the efficacies of the PACAP peptides cannot be attributed to species-specific differences in the mature peptides. PACAP27 has been shown to be more potent than PACAP38 in other cardiovascular responses (Warren et al., 1991; Cardell et al., 1997). Whether these responses also reflected expression of the very short receptor isoform will be of considerable interest in establishing tissue-specific expression and function of distinctive PAC1 receptor isoforms in neuroendocrine and cardiovascular physiology.

Among the different receptor isoforms produced by alternative splicing into the region encoding the third cytoplasmic loop, the minor expression of the PAC1HOP2 variant by cardiac neurons also appeared unusual because the HOP1 receptor form is more prevalent than HOP2 in many neuroendocrine tissues (Rawlings et al., 1995; K. Braas and V. May, unpublished observations). In transfected cells, PACAP receptors containing the HOP1 and HOP2 sequences are coupled to both adenylate cyclase and phospholipase C (Spengler et al., 1993). Whether selective PAC1HOP2 variant receptor expression imparts unique functional characteristics to cardiac neurons remains to be established.

The expression of PACAP in cardiac intraganglionic fibers and postganglionic neurons and the responsiveness of nearly $90 \%$ of postganglionic cardiac neurons to PACAP peptides have crucial implications for the current understanding of parasympathetic ganglia regulation of heart function. PACAP potently depolarized and increased markedly the excitability of guinea pig cardiac neurons, implying that PACAP peptides can act as excitatory neuromodulators amplifying the parasympathetic inhibition from guinea pig cardiac ganglia. Most of the guinea pig cardiac neurons 
are phasic, initiating one to two action potentials during long depolarizing current pulses, whereas few cardiac neurons are tonic, firing trains of action potentials on stimulation (Hardwick et al., 1995). The current studies demonstrating the ability of PACAP peptides to augment neuronal membrane excitability provides one mechanism by which PACAP may alter neuronal firing characteristics and transform a neuron with phasic properties to a tonic phenotype. Conversion of the firing pattern from phasic to tonic would greatly enhance the response of most cardiac neurons, resulting in increased parasympathetic inhibition of cardiac output.

The ionic mechanisms underlying the PACAP-induced increase in excitability remain to be elucidated, but our initial results have indicated that the changes were not direct consequences of peptide-induced membrane depolarization or alterations in action potential configuration, in particular, a decrease in the hyperpolarizing after potential. Preliminary results showed that the PACAP-induced increase in membrane excitability was not eliminated in the presence of $1 \mathrm{~mm}$ barium, indicating that the effects did not solely reflect inhibition of the noninactivating inward potassium conductance $\left(I_{\mathrm{M}}\right)$ (R. Parsons, unpublished results). Recently, Miura and co-workers (1997) reported that PACAP produced a similar increase in excitability of rat sacral preganglionic neurons, which these authors attributed to an inhibition of the fast inactivating potassium conductance $\left(I_{\mathrm{A}}\right)$. Inhibition of $I_{\mathrm{A}}$ by PACAP is a potential mechanism for the increase in excitability occurring in the cardiac neurons. The ionic basis for the observed PACAP response and the intracellular signaling mechanisms involved in modulating cardiac neuronal excitability are currently under study.

In summary, the present results demonstrated for the first time the presence of PACAP and PAC1 receptors in mammalian parasympathetic cardiac ganglia and provided direct evidence for PACAP peptide modulation of cardiac neuron excitability. The ability of PACAP peptides to regulate parasympathetic postganglionic cardiac neurons appears to reflect an important mechanism of refining the autonomic signals that determine cardiac output.

\section{REFERENCES}

Adams DJ, Harper AA (1995) Electrophysiological properties of autonomic ganglion neurons. In: Autonomic ganglia (McLanchlan EM, ed), pp 153-212. Luxembourg, Belgium: Harwood.

Akasu T, Nishimura T (1995) Synaptic transmission and function of parasympathetic ganglia. Prog Neurobiol 45:459-522.

Arimura A, Somogyvari-Vigh A, Weill C, Fiore RC, Tatsuno I, Bay V, Brenneman DE (1994) PACAP functions as a neurotrophic factor. Ann NY Acad Sci 739:228-243.

Basler I, Kuhn M, Muller W, Forssmann WG (1995) Pituitary adenylate cyclase-activating polypeptide stimulates cardiodilatin/atrial natriuretic peptide (CDD/ANP-(99-126)) secretion from cultured neonatal rat myocardiocytes. Eur J Pharmacol 291:335-342.

Beaudet MM, Braas KM, May V (1998) Pituitary adenylate cyclase activating polypeptide (PACAP) in sympathetic projection neurons to the superior cervical ganglion. J Neurobiol 36:325-336.

Braas KM, May V (1996) Pituitary adenylate cyclase-activating polypeptides, PACAP-38 and PACAP-27, regulation of sympathetic neuron catecholamine, and neuropeptide $\mathrm{Y}$ expression through activation of type I PACAP/VIP receptor isoforms. Ann NY Acad Sci 805:204-218.

Braas KM, Hendley ED, May V (1994a) Anterior pituitary proopiomelanocortin expression is decreased in hypertensive rat strains. Endocrinology 134:196-205.

Braas KM, Brandenburg CA, May V (1994b) Pituitary adenylate cyclase activating polypeptide regulation of AtT-20/D16v corticotrope cell proopiomelanocortin expression and secretion. Endocrinology 134:186-195.

Brandenburg CA, May V, Braas KM (1997) Identification of endogenous sympathetic neuron pituitary adenylate cyclase-activating polypeptide (PACAP): depolarization regulates production and secretion through induction of multiple propeptide transcripts. J Neurosci 17:4045-4055.

Cao YJ, Gimpl G, Fahrenholz F (1995) The amino-terminal fragment of the adenylate cyclase activating polypeptide (PACAP) receptor functions as a high affinity PACAP binding domain. Biochem Biophys Res Commun 212:673-680.

Cardell LO, Hjert O, Uddman R (1997) The induction of nitric oxidemediated relaxation of human isolated pulmonary arteries by PACAP. Br J Pharmacol 120:1096-1100.

Champion HC, Santiago JA, Garrison EA, Cheng DY, Coy DH, Murphy WA, Ascuitto RJ, Ross-Ascuitto NT, McNamara DB, Kadowitz PJ (1996) Analysis of cardiovascular responses to PACAP-27, PACAP-38 and vasoactive intestinal peptide. Ann NY Acad Sci 805:429-442.

Chatterjee TK, Liu X, Davisson RL, Fisher RA (1997) Genomic organization of the rat pituitary adenylate cyclase-activating polypeptide receptor gene. Alternative splicing within the $5^{\prime}$ untranslated region. J Biol Chem 272:12122-12131.

Couvineau A, Gaudin P, Maoret J-J, Rouyer-Fessard C, Nicole P, Laburthe M (1995) Highly conserved aspartate 68, tryptophane 73 and glycine 109 in the N-terminal extracellular domain of the human VIP receptor are essential for its ability to bind VIP. Biochem Biophys Res Commun 206:246-252.

DiCicco-Bloom E (1996) Region-specific regulation of neurogenesis by VIP and PACAP: direct and indirect modes of action. Ann NY Acad Sci 805:244-258.

Edwards FR, Hirst GD, Klemm MF, Steele PA (1995) Different types of ganglion cells in the cardiac plexus of guinea-pigs. J Physiol (Lond) 486:453-471.

Elsas T, Uddman R, Mulder H, Sundler F (1997) Pituitary adenylate cyclase activating polypeptide and nitric oxide synthase are expressed in the rat ciliary ganglion. Br J Ophthalmol 81:223-227.

Hardwick JC, Mawe GM, Parsons RL (1995) Evidence for afferent fiber innervation of parasympathetic neurons of the guinea-pig cardiac ganglion. J Auton Nerv Syst 53:166-174.

Hardwick JC, Mawe GM, Parsons RL (1997) Tachykinin-induced activation of non-specific cation conductance via $\mathrm{NK}_{3}$ neurokinin receptors in guinea-pig intracardiac neurons. J Physiol (Lond) 504:65-74.

Harmar T, Lutz E (1994) Multiple receptors for PACAP and VIP. Trends Pharmacol Sci 15:97-99.

Hashimoto H, Ishihara T, Shigemoto R, Mori K, Nagata S (1993) Molecular cloning and tissue distribution of a receptor for pituitary adenylate cyclase-activating polypeptide. Neuron 11:333-342.

Hashimoto H, Yamamoto K, Hagigara N, Ogawa N, Nishino A, Aino H, Nogi H, Imanishi K, Matsuda T, Baba A (1996) cDNA cloning of a mouse pituitary adenylate cyclase-activating polypeptide receptor. Biochim Biophys Acta 1281:129-133.

Hirose M, Furukawa Y, Nagashima Y, Yamazaki K, Hoyano Y, Chiba S (1997) Effects of PACAP38 on the SA nodal pacemaker activity in autonomically decentralized hearts of anesthetized dogs. J Cardiovasc Pharmacol 29:216-221.

Holgert H, Holmberg K, Hannibal J, Fahrenkrug J, Brimijoin S, Hartman BK, Hokfelt T (1996) PACAP in the adrenal gland-relationship with choline acetyltransferase, enkephalin and chromaffin cells and effects of immunological sympathectomy. NeuroReport 8:297-301.

Hosoya M, Onda H, Ogi K, Masuda Y, Miyamoto Y, Ohtaki T, Okazaki H, Arimura A, Fujino M (1993) Molecular cloning and functional expression of rat cDNAs encoding the receptor for pituitary adenylate cyclase activating polypeptide (PACAP). Biochem Biophys Res Commun 194:133-143.

Inagaki N, Yoshida H, Mizuta M, Mizuno N, Fujii Y, Gonoi T, Miyazaki J, Seino S (1994) Cloning and functional characterization of a third pituitary adenylate cyclase-activating polypeptide receptor subtype expressed in insulin-secretin cells. Proc Natl Acad Sci USA 91:2679-2683.

Ishihara T, Shigemoto R, Mori K, Takahashi K, Nagata S (1992) Functional expression and tissue distribution of a novel receptor for vasoactive intestinal polypeptide. Neuron 8:811-819.

Ishizuka Y, Kashimoto K, Mochizuk I T, Sato K, Ohshima K, Yanaihara N (1992) Cardiovascular and respiratory actions of pituitary adenylate cyclase activating polypeptides. Regul Pept 40:29-39.

Jeong SW, Wurster RD (1997) Calcium channel currents in acutely dissociated intracardiac neurons from adult rats. J Neurophysiol 77:1769-1778.

Kennedy AL, Harakall SA, Lynch SW, Braas KM, Hardwick JC, Mawe GM, Parsons RL (1998) Expression and physiological actions of neu- 
ropeptide $\mathrm{Y}$ in guinea pig parasympathetic cardiac ganglia. J Auton Nerv Syst 71:190-195.

Kimura C, Ohkubo K, Ogi K, Hosoya M, Itoh Y, Onda H, Miyata A, Jiang L, Dahl RR, Stibbs HH, Arimura A, Fujino M (1990) A novel peptide which stimulates adenylate cyclase: molecular cloning and characterization of the ovine and human cDNAs. Biochem Biophys Res Commun 166:81-89.

Konopka LM, Merriam LA, Hardwick JC, Parsons RL (1992) Aminergic and peptidergic elements and actions in a cardiac parasympathetic ganglion. Can J Physiol Pharmacol 70:S32-S43.

Journot L, Waeber C, Pantaloni C, Holsboer F, Seeburg PH, Bockaert J, Spengler D (1995) Differential signal transduction by six splice variants of the pituitary adenylate cyclase-activating peptide (PACAP) receptor. Biochem Soc Trans 23:133-137.

Lai CC, Wu SY, Lin HH, Dun NJ (1997) Excitatory action of pituitary adenylate cyclase activating polypeptide on rat sympathetic preganglionic neurons in vivo and in vitro. Brain Res 748:189-194.

Legradi G, Shioda S, Arimura A (1994) Pituitary adenylate cyclaseactivating polypeptide-like immunoreactivity in autonomic regulatory areas of the rat medulla oblongata. Neurosci Lett 176:193-196.

Loffelholz K, Pappano AJ (1985) The parasympathetic neuroeffector junction of the heart. Pharmacol Rev 37:1-24.

$\mathrm{Lu} \mathrm{N}$, DiCicco-Bloom E (1997) Pituitary adenylate cyclase-activating polypeptide is an autocrine inhibitor of mitosis in cultured cortical precursor cells. Proc Natl Acad Sci USA 94:3357-3362.

Lutz EM, Sheward WJ, West KM, Morrow JA, Fink G, Harmar AJ (1993) The $\mathrm{VIP}_{2}$ receptor: molecular characterization of a cDNA encoding a novel receptor for vasoactive intestinal peptide. FEBS Lett 334:3-8.

Mawe GM, Talmage EK, Lee KP, Parsons RL (1996) Expression of choline acetyltransferase immunoreactivity in guinea pig cardiac ganglia. Cell Tissue Res 285:281-286.

May V, Braas KM (1995) Pituitary adenylate cyclase-activating polypeptide (PACAP) regulation of sympathetic neuron neuropeptide $\mathrm{Y}$ and catecholamine expression. J Neurochem 65:978-987.

May V, Brandenburg CA, Braas KM (1995) Differential regulation of sympathetic neuron neuropeptide $\mathrm{Y}$ and catecholamine content and secretion. J Neurosci 15:4580-4591.

May V, Brandenburg CA, Braas KM (1996) Axotomy and decentralization regulate pituitary adenylate cyclase activating polypeptide (PACAP) expression in rat superior cervical ganglion. Soc Neurosci Abstr 22:1998.

May V, Beaudet MM, Parsons RL, Hardwick JC, Gauthier E, Durda JP, Braas KM (1998) Mechanisms of pituitary adenylate cyclase activating polypeptide (PACAP)-induced depolarization of sympathetic superior cervical ganglion (SCG) neurons. Ann NY Acad Sci, in press.

Mirfendereski S, Tobin G, Hakanson R, Ekstrom J (1997) Pituitary adenylate cyclase activating peptide (PACAP) in salivary glands of the rat: origin, and secretory and vascular effects. Acta Physiol Scand 160:15-22.

Miura A, Kawatani M, De Groat WC (1997) Effect of PACAP on preganglionic neurons in neonate rat lumbosacral parasympathetic nucleus. Soc Neurosci Abstr 23:1768.

Miyamoto Y, Habata Y, Ohtaki T, Masuda Y, Ogi K, Onda H, Fujino M (1994) Cloning and expression of a complementary DNA encoding the bovine receptor for pituitary adenylate cyclase-activating polypeptide (PACAP). Biochim Biophys Acta 1218:297-307.

Miyata A, Arimura A, Dahl RR, Minamino N, Uehara A, Jiang L, Culler MD, Coy DH (1989) Isolation of a novel 38 residue-hypothalamic polypeptide which stimulates adenylate cyclase in pituitary cells. Biochem Biophys Res Commun 164:567-574.

Moller K, Reimer M, Ekblad E, Hannibal J, Fahrenkrug J, Kanje M, Sundler F (1997) The effects of axotomy and preganglionic denervation on the expression of pituitary adenylate cyclase activating peptide (PACAP), galanin and PACAP type 1 receptors in the rat superior cervical ganglion. Brain Res 775:166-182.

Mulder H, Uddman R, Moller K, Elsas T, Ekblad E, Alumet J, Sundler F (1995) Pituitary adenylate cyclase activating polypeptide is expressed in autonomic neurons. Regul Pept 59:121-128.

Ogi K, Kimura C, Onda H, Arimura A, Fujino M (1990) Molecular cloning and characterization of cDNA for the precursor of rat pituitary adenylate cyclase activating polypeptide (PACAP). Biochem Biophys Res Commun 173:1271-1279.

Ogi K, Miyamoto Y, Masuda Y, Habata Y, Hosoya M, Ohtaki T, Masuo Y, Onda H, Fujino M (1993) Molecular cloning and functional expression of a cDNA encoding a human pituitary adenylate cyclase activating polypeptide receptor. Biochem Biophys Res Commun 196:1511-1521.

Ohkubo S, Kimura C, Ogi K, Okazaki K, Hosoya M, Onda H, Miyata A, Arimura A, Fujino M (1992) Primary structure and characterization of the precursor to human pituitary adenylate cyclase activating polypeptide. DNA Cell Biol 11:21-30.

Okazaki K, Itoh Y, Ogi K, Ohkubo S, Onda H (1995) Characterization of murine PACAP mRNA. Peptides 16:1295-1299.

Pantaloni C, Brabet P, Bilanges B, Dumuis A, Houssami S, Spengler D, Bockaert J, Journot L (1996) Alternative splicing in the N-terminal extracellular domain of the pituitary adenylate cyclase-activating polypeptide (PACAP) receptor modulates receptor selectivity and relative potencies of PACAP-27 and PACAP-38 in phospholipase C activation. J Biol Chem 271:22146-22151.

Randall WC, Wurster RD (1994) Peripheral innervation of the heart. In: Vagal control of the heart: experimental basis and clinical implications (Levy MN, Schwartz PJ, eds), pp 21-32. Armonk, NY: Futura.

Rawlings SR (1994) PACAP, PACAP receptors, and intracellular signalling. Mol Cell Endocrinol 101:C5-C9.

Rawlings SR, Hezareh M (1996) Pituitary adenylate cyclase-activating polypeptide (PACAP) and PACAP/vasoactive intestinal peptide receptors: actions on the anterior pituitary gland. Endocr Rev 17:4-29.

Rawlings SR, Piuz I, Schlegel W, Bockaert J, Journot L (1995) Differential expression of pituitary adenylate cyclase-activating polypeptide/ vasoactive intestinal polypeptide receptor subtypes in clonal pituitary somatotrophs and gonadotrophs. Endocrinology 136:2088-2098.

Seebeck J, Schmidt WE, Kilbinger H, Neumann J, Zimmermann N, Herzig S (1996) PACAP induces bradycardia in guinea-pig heart by stimulation of atrial cholinergic neurones. Naunyn Schmiedebergs Arch Pharmacol 354:424-430.

Spengler D, Waeber C, Pantaloni C, Holsboer F, Bokaert J, Seeburg PH, Journot L (1993) Differential signal transduction by five splice variants of the PACAP receptor. Nature 365:170-175.

Steele PA, Gibbons IL, Morris JL, Mayer B (1994) Multiple populations of neuropeptide-containing intrinsic neurons in the guinea-pig heart. Neuroscience 62:241-250.

Sundler F, Ekblad E, Hannibal J, Moller K, Zhang Y-Z, Mulder H, Elsas T, Grunditz T, Danielsen N, Fahrenkrug J, Uddman R (1996) Pituitary adenylate cyclase-activating peptide in sensory and autonomic ganglia: localization and regulation. Ann NY Acad Sci 805:410-428.

Tanaka K, Shibuya I, Nagamoto T, Yamashita H, Kanno T (1996) Pituitary adenylate cyclase-activating polypeptide causes rapid $\mathrm{Ca}^{2+}$ release from intracellular stores and long lasting $\mathrm{Ca}^{2+}$ influx mediated by $\mathrm{Na}^{+}$influx-dependent membrane depolarization in bovine adrenal chromaffin cells. Endocrinology 137:956-966.

Tobin G, Asztely A, Edwards AV, Ekstrom J, Hakanson R, Sundler F (1995) Presence and effects of pituitary adenylate cyclase activating peptide in the submandibular gland of the ferret. Neuroscience 66:227-235.

Villalba M, Bockaert J, Journot L (1997) Pituitary adenylate cyclaseactivating polypeptide (PACAP-38) protects cerebellar granule neurons from apoptosis by activating the mitogen-activated protein kinase (MAP kinase) pathway. J Neurosci 17:83-90.

Warren JB, Donnelly LE, Cullen S, Robertson BE, Ghatei MA, Bloom SR, MacDermot J (1991) Pituitary adenylate cyclase-activating polypeptide: a novel, long-lasting, endothelium-independent vasorelaxant. Eur J Pharmacol 197:131-134.

Yonezawa T, Furukawa Y, Lakhe M, Nagashima Y, Hirose M, Chiba S (1996) PACAP-38 activates parasympathetic nerves in isolated, bloodperfused dog atria. Eur J Pharmacol 315:289-296.

Zhang Q, Shi TJ, Ji RR, Zhang YZ, Sundler F, Hannibal J, Fahrenkrug $J$, Hokfelt $T$ (1995) Expression of pituitary adenylate cyclaseactivating polypeptide in dorsal root ganglia following axotomy: time course and coexistence. Brain Res 705:149-158. 